\title{
BANKING AND THE LIMITS OF PROFESSIONALISM
}

\author{
DIMITY KINGSFORD SMITH,* THOMAS CLARKE** AND JUSTINE ROGERS***
}

\section{INTRODUCTION}

Few other occupations that aspire to professional status have the influence, both beneficial and destructive, or the raw power to resist regulation and political constraint, that banking has. The global financial crisis ('GFC') and revelations of bank manipulation of the benchmark London Inter-bank Offering Rate ('LIBOR'), ${ }^{1}$ which followed quickly afterwards, showed devastatingly the worst of this influence and power. These failings have been diagnosed as stemming from a foundational collapse in the values of individuals and in the governance of banking entities. ${ }^{2}$ The critique has concentrated on demands for better decisions and conduct from individuals, as well as changes in the entities for which they work, to better support those individuals. This post-GFC prescription for banking has turned attention to the professions as a possible framework for promoting individual ethical conduct in banking. ${ }^{3}$ Indeed, since the LIBOR revelations, even banking itself has expressed a desire to professionalise. ${ }^{4}$

* $\quad$ Professor and Director of the Centre for Law, Markets and Regulation ('CLMR') University of New South Wales ('UNSW'); LLM (London School of Economics, London) LLB (Sydney) BA (Sydney). Correspondence to Professor Kingsford Smith < d.kingsfordsmith@unsw.edu.au>.

** Professor of Management and Director of the Key University Research Centre for Corporate Governance, University of Technology Sydney; PhD (Warwick) BSocSc (Birm).

*** Lecturer, UNSW Law; DPhil (Oxford) MSc (Oxford).

The authors acknowledge the support of the Australian Research Council and the Professional Standards Councils for this work and particularly the comments of the anonymous referees and of fellow researcher, Hugh Breakey, on an earlier version of this paper and the work of Senior Research Fellow, John Chellew. The authors also acknowledge the support of the CLMR at UNSW Law, particularly the work of CLMR interns, Katherine Roderick and Miles Ma.

1 See Intercontinental Exchange, ICE LIBOR (2017) <https://www.theice.com/iba/libor>.

2 British Broadcasting Corporation, 'Market and Morals: A New Citizenship', The Reith Lectures: 2009, 9 June 2009 (Michael Sandel) <www.bbc.co.uk/programmes/b00kt7sh>; Grant Kirkpatrick, 'Corporate Governance Lessons from the Financial Crisis' [2009] (1) OECD Journal: Financial Market Trends 61; John R Boatright, 'Swearing to Be Virtuous: The Prospects of a Banker’s Oath’ (2013) 71 Review of Social Economy 140; Bert van de Ven, 'Banking after the Crisis: An Understanding of Banking as a Professional Practice’ (2011) 18 Ethical Perspectives 541.

3 van de Ven, above $n 2$.

4 'The new leaders of the largest banks have been vocal in disowning the previous regime, admitting mistakes and pledging a new approach': see Joint Parliamentary Commission on Banking Standards, Changing Banking for Good: Report of the Parliamentary Commission on Banking Standards - Volume 
There were several factors involved in the GFC financial collapse: low interest rates globally, a housing bubble in the US fuelled by US banks' securitisation practices, ${ }^{5}$ mis-selling which spread highly risky financial interests to financial institutions across the globe, ${ }^{6}$ failures by regulators ${ }^{7}$ and an overall preference for the profits of the banks conducting these transactions in disregard of the interests of other stakeholders involved. ${ }^{8}$ The LIBOR manipulations targeted a leading benchmark of the international financial infrastructure, against which national and international interest rates are set worldwide. The rates thereby set may influence the cost of capital and rates of economic growth. ${ }^{9} \mathrm{We}$ are therefore discussing entities and individuals whose decisions and conduct have profound economic, social and political consequences.

Our primary question is whether banking could become a profession. We start challenged by the insight of our co-author Thomas Clarke that the business terrain of finance is the most hazardous on which to establish the practices of a profession. Likewise, evidence to the 2013 United Kingdom ('UK') Parliamentary Commission into Banking Conduct suggested that banking may once have been considered a profession, ${ }^{10}$ but that it is no longer considered one, and has certainly not been a profession since the 1980s. It also indicated that banking, if it ever were a profession, is not an occupation ready for 'reprofessionalisation' ${ }^{11}$ So, we start from the position that whether banking is, or might become, a profession is not obvious, for a number of reasons. The first is the intense government regulation which is generally the primary mode of securing the benefits of banking and limiting its undesirable effects. External regulation tends to be regarded as a definitional and practical threat to the selfregulation that marks out traditional professionalism. Second, traditional

II, House of Lords Paper No 27-II, House of Commons Paper No 175-II, Session 2013-14 (2013) ('Changing Banking for Good vol II') 166.

5 John B Taylor, 'The Financial Crisis and the Policy Responses: An Empirical Analysis of What Went Wrong' (Working Paper No 14631, National Bureau of Economic Research, Stanford University, January 2009) 2, 5-7; Financial Crisis Inquiry Commission, 'The Financial Crisis Inquiry Report: Final Report of the National Commission on the Causes of the Financial and Economic Crisis in the United States' (2011) 42-5, 127-9 ('Financial Crisis Inquiry Report'); Gillian Tett, Fool’s Gold: How Unrestrained Greed Corrupted a Dream, Shattered Global Markets and Unleashed a Catastrophe (Little, Brown, 2009) 48-65 and generally.

6 See generally Joseph Stiglitz, Freefall: America, Free Markets and the Sinking of the World Economy (W W Norton \& Company, 2010); Tett, above n 5, 66-82.

$7 \quad$ Raghuram G Rajan, Fault Lines: How Hidden Fractures Still Threaten the World Economy (Princeton University Press, 2010) 101-14, 148-52; Charles A E Goodhart, The Regulatory Response to the Financial Crisis (Edward Elgar, 2009) 56. See generally Howard Davies, The Financial Crisis: Who is to Blame? (Polity, 2010).

8 Tett, above n 5, 287-9, 298-301; British Broadcasting Corporation, above n 2; van de Ven, above n 2 541-51.

9 David Hou and David Skeie, 'LIBOR: Origins, Economics, Crisis, Scandal and Reform' (Staff Reports No 667, Federal Reserve Bank of New York, March 2014) 7-9, 12. The LIBOR has come to public attention recently because, in 2012, it was discovered that a number of global banks were wrongfully collaborating to manipulate the LIBOR for their own financial advantage.

10 Changing Banking for Good vol II, above n 4, 295-6, quoting Evidence to Joint Parliamentary Commission on Banking Standards, United Kingdom, 14 January 2014, Q 2403, Ev 926 (Simon Thompson, Chief Executive of the Chartered Banker Institute). See also van de Ven, above n 2.

11 Changing Banking for Good vol II, above n 4, 391. 
professional logic is said to promote as one of its distinguishing features a contrast with, and at least to some extent a corrective to the world of business, a world 'dominated by large bureaucratic organizations, competitive markets, managerial control, deskilling or dehumanizing tendencies and a markedly forprofit logic'. ${ }^{12}$ Meanwhile, some bankers, including those who advocate change, perceive profit-making as integral to banking. Evidence to the Inquiry included the view of a senior banker that: 'Banking is a strictly profit-making business, and is not, and never has been, a profession in the sense that, say, medicine or law is'. ${ }^{13}$

Third, directly at odds with the last opinion and perhaps most challenging of all, is whether banking could ever act in the public interest, the leading feature of established professions if not always enacted. Behind the demands for greater professionalism lies an unspoken assumption that somehow 'professionalising' will increase banks' loyalty to the public interest in preserving and advancing important financial institutions, ${ }^{14}$ the way medicine does for public health and law for the legal system. There is also the assumption that it will improve the motivations, attitudes, cultures and conduct relating to the treatment of clients or consumers and likewise to other traditional professional beneficiaries, including colleagues and the occupation itself. Our discussion of these latter challenges comprises the core of this article. We also consider the underlying assumption that having an altruistic or public-regarding purpose actually does inspire higher standards of individual conduct. Having reviewed the slim and difficult evidence on this question, this article adopts a transparently normative outlook to its question. We argue that the most powerful occupations should serve a paramount duty to the public interest in important social and economic institutions. Demands for professionalism, such as we make here, are important, as Breakey argues, for 'the construction, reform or continuance of a professional ethos' and as a spur to 'the ethical materiel out of which [professional] norms emerge'. ${ }^{15}$ We are examining whether, in banking, the basic structures, processes and beliefs are present to support a public interest, which might be formulated provisionally as a duty to foster a 'resilient, fair and efficient financial system', ${ }^{16}$ and likewise support client and community trust in banking. In short, does banking have what it takes to professionalise, so that it might fare better than has been the case under

12 Daniel Muzio and John Flood, 'Entrepreneurship, Managerialism and Professionalism in Action: The Case of the Legal Profession in England and Wales’ in Markus Reihlen and Andreas Werr (eds), Handbook of Research on Entrepreneurship in Professional Services (Edward Elgar Publishing, 2012) 369.

13 Changing Banking for Good vol II, above n 4, 295, quoting Evidence to Joint Parliamentary Commission on Banking Standards, United Kingdom, 28 July 2012, Ev 1168 (Neil Jeffares, former senior City of London banker).

14 van de Ven, above $\mathrm{n} 2$.

15 Hugh Breakey, 'Supply and Demand in the Development of Professional Ethics' in Marco Grix and Tim Dare (eds), Contemporary Issues in Applied and Professional Ethics (Research in Ethical Issues in Organizations vol 15, Emerald Group Publishing, 2016) 1.

16 The Financial System Inquiry Committee, 'Financial System Inquiry Final Report' (Commonwealth of Australia, November 2014) ('Murray Report') argued at Xv that the basic characteristics or principles of a financial system to be properly functioning are that it should be 'efficient' 'resilient', 'and 'fair'. 
regulation of legislative origin or the 'chaos and self-interest of the market'? ${ }^{17}$ It is not enough to say that higher service delivery levels to clients or absence of misleading practices amounts to professionalism. These are welcome, but they are far from the sum total of being a professional or acting as a profession.

To engage in this discussion about whether banking has features that make it amenable to professionalising introduces one of the familiar debates in the sociological literature: whether there are traits and standards of professionalism adequately stable and empirically grounded to legitimately assess their qualities. Traditional professions have tended to describe groups of individuals pursuing worthwhile economic activities, driven and integrated by practices and values of autonomy and moral obligation. Bolstering the social order that these practices are said to advance have been the professional associations and their sets of professional ethics. ${ }^{18}$ This interpretation has been supplemented by an understanding of the special social status of professions as a consequence of their guardianship of 'superior "technical competence"' ${ }^{19}$ These occupational qualities mean that their organisation is rightfully and, indeed needs to be, an alternative to market relations and government - and now workplace - bureaucracy. ${ }^{20}$

As detailed in an earlier article in this Issue, ${ }^{21}$ however, and some of many difficulties in this discussion, the meanings of professionalism, which regularly come from professions themselves, are often contradictory. ${ }^{22}$ They are replete with 'stereotypes, rhetorical claims and deceptive appearances'. ${ }^{23}$ The established professions' conceptions and practices of public service can mean, in effect, supporting their own economic and status projects ${ }^{24}$ and the conservation of their institutions. As a final example here, professionalism is not a static social construct; its meanings change over time. Professions themselves have created, been beset by, and had to adapt to huge social changes and challenges. In the process, the contours and standards of professionalism have changed such that they entail values, discourses and practices closer to commercialism and managerialism. ${ }^{25}$ Most professionals still work in small partnerships, as sole practitioners or in government institutions, grounded in particular regions or

17 Christine Parker and Tanina Rostain, 'Law Firms, Global Capital and the Sociological Imagination’ (2012) 80 Fordham Law Review 2347, 2356.

18 Emile Durkheim, Professional Ethics and Civic Morals (Cornelia Brookfield trans, Free Press, 1958) 7-8 [trans of: 'Leçons de sociologie: Physique des mœurs et du droit, first published 1950].

19 Talcott Parsons, 'The Professions and Social Structure' (1939) 17 Social Forces 457, 460.

20 Parker and Rostain, above n 17.

21 Justine Rogers, Dimity Kingsford Smith and John Chellew, 'The Large Professional Service Firm: A New Force in the Regulative Bargain’ (2017) 40 University of New South Wales Law Journal 218.

22 Justine Rogers, 'Representing the Bar: How the Barristers' Profession Sells Itself to Prospective Members' (2012) 32 Legal Studies 202; David Sugarman and W Wesley Pue (eds), Lawyers and Vampires: Cultural Histories of Legal Professions (Hart Publishing, 2003).

23 Muzio and Flood, above n 12, 369.

24 Magali Sarfatti Larson, The Rise of Professionalism: A Sociological Analysis (University of California Press, 1979) xvii.

25 See Rogers, Kingsford Smith and Chellew, above n 21. 
communities. However, as also examined in this Issue, ${ }^{26}$ professionals are increasingly working like bankers in large corporations with national or worldwide office networks and a mobile and often international workforce. In essence, professions are themselves struggling to fit the archetypes of traditional professionalism. Commentators have pointed out that the variety of failures of technical competence and ethical conduct in finance has not excluded professionals at whose door a portion of responsibility must be laid for the damage done to financial resilience by the GFC and other economic failures. ${ }^{27}$ They might wonder how and why professionalising would succeed in improving occupational conduct standards where state regulation has failed and when professions themselves have also failed.

Notwithstanding these views, writers on the professions understand that some of how professional control and its related privilege are secured and advanced continues to be through local political and social legitimacy or some form of public connection. This control and its basis have not been entirely impaired by their increasingly vast and variable business environments. As Breakey argues, the demand for professional standards and conduct may come not only from professionals themselves, but from clients and the wider public who benefit from the goods of professional work. ${ }^{28}$ There are also several motivations for the supply of the 'ethical materiel' of professions that are not just spurred by business advantage, but by more metaphysical and personal factors. ${ }^{29}$ Further, as we have signalled, these conceptions of professionalism and business are archetypes, ideal-type constructions with primarily heuristic, rather than descriptive, qualities and functions..$^{30}$

Other authors writing about what it might take to professionalise the financial sector have recognised this need to inculcate values and invigorate otherregarding cultures in banking, including a duty to the public interest. ${ }^{31}$ However, much of this opinion has focused narrowly on the benefit to customers, criticising practices 'that reward high-risk, short-term strategies [as] a clear indicator of a culture where the customer is not at the centre of how the business is run' ${ }^{32}$ Hall and Appleyard's empirical work emphasises the role of in-house firm training as

26 Ibid; Hugh Breakey and Charles Sampford, 'Employed Professionals’ Ethical Responsibilities in Public Service and Private Enterprise: Dilemma, Priority and Synthesis’ (2017) 40 University of New South Wales Law Journal 262.

27 John C Coffee, Jr, 'Understanding Enron: It’s about the Gatekeepers, Stupid' (2002) 57 The Business Lawyer 1403; John C Coffee Jr, Gatekeepers: The Professions and Corporate Governance (Oxford University Press, 2006).

28 Breakey, above $\mathrm{n} 15,1$.

29 Ibid 1 (emphasis added). Breakey considers desirable role identity; a desire for standards of excellence; adherence to common morality such as honesty, integrity and fairness; meeting expectations of tacit or regulative contracts with society and a desire for social admiration of their work.

$30 \quad$ Muzio and Flood, above n 12, 372.

31 Boatright, above n 2; van de Ven, above n 2; British Broadcasting Corporation, above n 2.

32 Financial Conduct Authority, 'FCA Risk Outlook 2013' (2013) 6, quoted in Roger McCormick and Chris Stears, 'Banks: Conduct Costs, Cultural Issues and Steps towards Professionalism' (2014) 8 Law and Financial Markets Review 134, 136. 
distinct from university education in embedding this view. ${ }^{33}$ Our contribution here is in extending what we could expect of banking by applying the full range of the established elements of professional logic, which is significantly wider than simply 'putting clients first'. As mentioned, professionalism has several interests and beneficiaries, including the client, but also the government, professional entities and associations, professionals themselves and, most importantly for the initial and continuing recognition of an occupation as a profession, the public and wider community. In outlining what we are looking for as features of professionalism, we note that we are dealing here with a phenomenon that can be observed and measured in myriad ways, right down to personal conscience and integrity. Recognising this and to provide limits on our article, we examine three central demands or duties of professionalism imposed on individuals that allow us to best capture and explore the selflessness that is not always observed in professions, but should be.

To set up our argument in Part II, we outline two of the leading difficulties of regulating banking, namely the focus on controlling entities in the sector and their scale and complexity, and the ubiquitous presence of high remuneration for individuals (or at least an expectation of it). In Parts III, IV and V, we examine in detail the fit between banking and the professional duty to the public, duty to the client and duty to peers and to the profession respectively. In Part VI, we analyse another element of traditional professions: the role of professional associations. Associations are both representatives and regulators, and we consider particularly the challenges they face in the enforcement of professional duties in the banking sector. After reviewing the three central professional duties and associations, we conclude that banking faces challenges in trying to professionalise as an entire occupational group. This, in turn, raises the question about what professionalism and professions might still have to offer, even if it seems impossible to fully professionalise such a vast industry, at least as a whole. On this subsequent question of what banking might look like if it were to truly professionalise, we make some opening suggestions for a longer program of research, acknowledging that, as the sector is already highly regulated, professional duties will have to work alongside regulation and regulatory agency involvement. Finally, by examining the limits of professionalism in the banking sector, by inference, our argument also considers whether in other occupations, demands for professionalising can be realised and, if they cannot, what professional logic may still have to offer.

Before beginning on the substance of our argument, there is one further vital clarification. We speak from our title onwards about 'banking'. However, we use it as a shorthand term for 'banking and finance', for in the powerful national and global institutions we are considering, banks and other non-banking financial institutions operate intertwined. Except to save words, it makes no sense to consider one without the other. Prior to the deregulation of stock exchanges in

33 Sarah Hall and Lindsey Appleyard, “"City of London, City of Learning”? Placing Business Education within the Geographies of Finance’ (2009) 9 Journal of Economic Geography 597, 609. 
the United States ('US') and the UK ${ }^{34}$ most of the credit and investment functions in financial markets were conducted by separate, independent businesses. ${ }^{35}$ The overall effect of deregulation was their acquisition by large, often global entities, which were usually commercial banks or investment banks. This conglomeration of what had previously been separate financial functions of credit provision, on the one side, and a variety of investment functions, on the other, has led to the intertwining of banking and finance. In particular, it has resulted in the hybridisation of financial products melded from these two elements. The securitisation and sale as investments of US housing loans mentioned in the opening as a cause of the GFC is one example of this melding of credit and investment arising from the conglomeration of functions associated with amalgamation of ownership. As the reader will see, many of the difficulties of professionalising are connected with these intertwined consequences of deregulation: large conglomerate organisations offering clients products and services from related parties within the organisation and associated conflicts of interest and risk.

\section{TWO PROBLEMS WITH BANKING: COMPLEX ORGANISATIONS AND INDIVIDUAL REMUNERATION}

In this Part, we concentrate on two important obstacles to good governance and conduct: complex banking organisations and individual remuneration. We do this to point out the limits of legislative and regulatory agency action and to demonstrate the conduct and compliance gap that professionalising banking might fill.

The GFC and the accompanying disappearance of bank credit demonstrated the umbilical connection between banking and business prosperity, and the linkages to wealth, employment and tax revenue. ${ }^{36}$ The disregard of financial safety in risky transactions, where a professional might have had influence,

34 After the so-called 'Big Bang' at the London Stock Exchange on 27 October 1986, rules requiring fixed minimum commissions were abolished, along with the 'single capacity' rule which separated the work of stockbrokers, who acted for investors, and that of ‘jobbers' (or ‘market makers' as known in Australia and the United States), who made a market by holding lines of stock available for purchase. Also abolished was the requirement that both brokers and jobbers should be independent and not part of any wider financial group. The stock exchange rules excluding all foreigners from stock exchange membership were also abolished. Similar reforms had begun at the New York Stock Exchange when the Securities Exchange Commission abolished fixed commissions for all trades of $\$ 500000$ and above in 1973. Other exchanges around the world eventually followed suit in the late 1980s and early 1990s.

35 In the US this separation was originally required by and substantially because of the Banking Act of 1933, Pub L No 73-66, 48 Stat 162 (1933), universally known as the 'Glass-Steagall Act'. The financial sector changed because of deregulation at the stock exchanges, and also because of repeal of parts of the GlassSteagall Act by the Gramm-Leach-Bliley Act 1999, Pub L 106-102, 113 Stat 1338 (1999). These changes in US banks had influence wherever they did business.

36 For an outline of the scale of the impact of the GFC and the extensive measures required to remedy this, see Barack Obama and the Council of Economic Advisers, 'Economic Report of the President: Together with the Annual Report of the Council of Economic Advisers’ (Report, The White House, January 2017) $<$ https://obamawhitehouse.archives.gov/sites/default/files/docs/2017_economic_report_of_ president.pdf $>$. 
eventually accumulated in devastating losses to individuals ${ }^{37}$ and damage to economic prosperity and the welfare of the global public. The resulting loss of trust in banking institutions and personnel was compounded by the revelation of misconduct involved in setting the LIBOR interest rate. Over nearly a century, banking has accrued some of the most complex and extensive regimes of regulation in developed economies. In the wake of the GFC and LIBOR crises, these were subject to intense scrutiny for having failed to prevent poor conduct. They also underwent considerable reform; yet, as seems to be a widely held opinion, the changes have not been as effective as hoped. This disappointment is one of the factors that have led to greater emphasis on individual ethics and conduct, and demands for professionalism in the sector.

\section{A Organisational Restructuring and Reform}

Although there are aspects of banking regulation that impose responsibility and accountability on individuals, the basic unit of regulatory attention is the provider entity. This is primarily through the regulatory techniques of licensing, mandating capital and other resources for the proper conduct of the business, entity supervision and, if appropriate, enforcement and sanctions against the entity, such as fines..$^{38}$ While lately more attention is being given to responsible persons or managers, ${ }^{39}$ the calibre of personnel, and 'risk culture' in regulatory standards, ${ }^{40}$ it is still mainly seen as an entity requirement to have proper capabilities and resources, not a question of individual ethical or legal responsibility. This concentration on entity regulation is one of the myriad structural features that act as obstacles to professionalism in banking.

Further, most financial institutions present critical problems of scale, concentration, complexity and interconnection, combined with digital technology operating at the speed of light. These represent what appear as insuperable structural challenges to managers, professionals and regulators trying to do the right thing. ${ }^{41}$ In these circumstances, there is a question whether the logic of

37 Susan Bell Research, 'Compensation for Retail Investors: The Social Impact of Monetary Loss' (Report No 240, Australian Securities and Investments Commission, 19 May 2011).

38 But see criticisms of the US Securities Exchange Commission prosecution settlements against US banks by Justice Jed Rakoff: Nate Raymond, 'Judge Criticizes Lack of Prosecution against Wall Street Executives for Fraud’, Reuters (online), 12 November 2013 <http://www.reuters.com/article/us-financialjudge-idUSBRE9AC00O20131113>.

39 See Changing Banking for Good vol II, above n 4, 8-9.

40 See, eg, Ian Laughlin, 'Stay Ahead of the Risk: Risk Governance and Risk Culture' (Speech delivered at the Institute of Actuaries of Australia, Sydney, 20 May 2013) <http://www.apra.gov.au/Speeches/ Documents/Ian-Laughlin-IAA-20-May-2013.pdf>; Jonathon Shapiro, 'APRA Steps Up Culture Crusade as ASIC Rate Probe Heats Up’, Sydney Morning Herald (online), 11 February $2016<$ http://www.smh. com.au/business/banking-and-finance/apra-steps-up-culture-crusade-as-asic-rate-probe-heats-up20160210-gmqtv4.html>; Greg Medcraft, Chairman of the Australian Securities and Investments Commission, 'Good Corporate Culture, Values and Ethics' (Speech delivered at the Launch of Governance Institute of Australia’s Inaugural Ethics Index, Sydney, 20 July 2016) <http://download. asic.gov.au/media/3951997/greg-medcraft-speech-launch-of-governance-institute-inaugural-ethics-index20-july-2016.pdf>.

41 Stijn Claessens, Richard J Herring and Dirk Schoenmaker, 'A Safer World Financial System: Improving the Resolution of Systemic Institutions’ (Geneva Reports on the World Economy No 12, International 
professionalism runs the risk of exposing individuals to an impossible task of maintaining conduct standards in a profoundly inimical environment. Indeed, as other articles in this Issue argue, ${ }^{42}$ the position of professionals working in large organisations is evolving, even when the entities they are employed by are professional firms, rather than banks. Those articles also point out the need for, and the difficulties in, making professional firms themselves subject to professional obligations in order to better support individual professionals.

The evidence of these structural challenges to individual action is seen in analysis from all major financial centres. Haldane, at the Bank of England, argues:

The past fifty years have seen seismic shifts in the structure, size and composition of the global financial system. These changes gave birth to the too-big-to-fail problem ... Accompanying this dramatic rise in banking scale has been an equally-dramatic rise in banking concentration. ${ }^{43}$

The UK Parliamentary Banking Inquiry, referring to the losses incurred by British taxpayers in the government rescue packages following the GFC, found that 'the events which led to that loss were the result of pervasive structural weaknesses, rather than the failings of a few individuals' ${ }^{44}$ In the US, Philip Wallach has despaired that

being a bank director has become 'a job that passeth understanding', requiring inhuman foresight and perspicacity. With hundreds of corporate subdivisions to oversee and many hundreds of requirements for the board members of [systemically important financial institutions], it is easy to see how capacity for oversight (both corporate and regulatory) can be overwhelmed. ${ }^{45}$

Wallach cites Vincent Reinhart's evidence to a US Senate Committee that: 'The opacity of byzantine corporate structures makes it impossible for regulators to do their jobs, for markets to evaluate firms' stability or value, and for banks' managers to run their companies safely'. ${ }^{46}$

Along with the issues of the entity versus individuals and the size and complexity of group business forms, a further, crucial structural problem discussed in Part IV is the coexistence of retail and commercial banking services

Center for Monetary and Banking Studies and Centre for Economic Policy Research, July 2010) ch 1; Thomas M Hoenig and Charles S Morris, 'Restructuring the Banking System to Improve Safety and Soundness’ (Paper, revised ed, December 2012); Karen Shaw Petrou, 'A Job that Passeth Understanding: Or, Can Anyone Be a Bank Director Anymore?' (Speech delivered at the $21^{\text {st }}$ Annual Corporate Governance Conference, Kellogg School of Management, Northwestern University, 8 May 2012) $<$ http://www.fedfin.com/images/stories/press_center/speeches/Kellogg\%20School\%20of\%20 Management_Speech.pdf $>$.

42 Rogers, Kingsford Smith and Chellew, above n 21; Breakey and Sampford, above n 26.

43 Andrew Haldane, 'On Being the Right Size' (Speech delivered at the Institute of Economic Affairs' $22^{\text {nd }}$ Annual Series, Institute of Directors, London, 25 October 2012) $2<$ http://www.bis.org/review/ r121030d.pdf $>$.

44 Changing Banking for Good vol II, above n 4, 83.

45 Philip Wallach, 'Moving Beyond Calls for a "New Glass-Steagall”' (2012) 51 Issues in Governance Studies 1, 12.

46 Ibid; Evidence to Senate Committee on Banking, Housing and Urban Affairs, United States Congress, Washington DC, 23 July 2009 (Vincent Reinhart) <http://www.banking.senate.gov/public/_cache/files/ c00a4670-8edd-4a6e-947f-09afb555fa4d/33A699FF535D59925B69836A6E068FD0. reinhart testimony72309.pdf>. 
working for the real economy with the bank's own proprietary trading activities. The latter function serves purposes related to the financial economy and the banks' profitability and has been the chief contributor to the growth, internationalisation and riskiness of bank activities. All these institutional features have been intensified following the financial crisis by the takeover of smaller competitors, augmenting systemic risk. ${ }^{47}$

Arguments for reform to address these systemic risks include changes to achieve more effective competition, customer choice and better governance. These proposals and some actual reforms to the sector amount to a 'reassessment of the economic costs and benefits of universal banks' involvement in proprietary trading and other securities markets activities' ${ }^{48}$ The reforms have seen the development of different approaches ${ }^{49}$ for the renewed separation of 'commercial' and 'investment' banking, intended 'to insulate certain types of financial activities regarded as especially important for the real economy, or significant on consumer or depositor protection grounds, from the risks that emanate from potentially riskier but less important activities', ${ }^{50}$ In the $\mathrm{US}^{51}$ and the UK, ${ }^{52}$ and potentially throughout the European Union ('EU'), ${ }^{53}$ these reforms to effect structural separation of ordinary banking business from riskier securities and proprietary trading are hoped to render banks safer and reduce the

47 Haldane, above n 43, 6; European Commission, 'European Financial Stability and Integration' (Working Document, April 2015) <http://ec.europa.eu/info/file/31532/download_en?token=woT7k0v5> 85; Hoenig and Morris, above n 40.

48 Leonardo Gambacorta and Adrian van Rixtel, 'Structural Bank Regulation Initiatives: Approaches and Implications’ (Working Paper No 412, Bank for International Settlements, April 2013) 1.

49 Ibid.

50 Ibid.

51 See, eg, the 'Volcker Rule', enacted in 2010, which aims to limit the extent to which commercial deposittaking banks, compared with investment banks, in the US can proprietary trade - that is, trade their own, rather than client, accounts: Dodd-Frank Wall Street Reform and Consumer Protection Act, 12 USC §§ 5301-5641 (2012) ('Dodd-Frank Act'). The full implementation of this Rule, however, continues to be delayed: see, eg, Olivia Oran, 'Exclusive - Wall St Banks Ask Fed for 5 More Years to Comply with Volcker Rule’ CNBC (online), 11 August 2016 <http://www.cnbc.com/2016/08/11/reuters-americaexclusive-wall-st-banks-ask-fed-for-5-more-years-to-comply-with-volcker-rule.html>.

52 See, eg, Independent Commission on Banking, 'Final Report: Recommendations' (Government of the United Kingdom, September 2011) ('Vickers Report'), which proposed that UK banks should 'ringfence' their commercial banking assets from their higher risk investment banking operations, including derivatives speculation. Subsequent enactment of the Vickers Report recommendations in the Financial Services (Banking Reform) Act 2013 (UK) are proposed to be fully implemented by 2019: Allen \& Overy, Legal and Regulatory Risks for the Financial Sector: The Banking Reform Act 2013

$<$ http://www.allenovery.com/publications/en-gb/lrrfs/uk/Pages/The-Banking-Reform-Act-2013.aspx>.

53 See, eg, High-Level Expert Group on Reforming the Structure of the EU Banking Sector, 'Final Report' (2 October 2012) <http://ec.europa.eu/internal_market/bank/docs/high-level_expert_group/ report_en.pdf> ('Liikanen Report'). It proposed, among other things, that 'proprietary trading and other significant trading activities should be assigned to a separate legal entity if the activities to be separated amount to a significant share of a bank's business': at iii. While this proposal has not been legislated, there has been active consideration across Europe of three broad forms of separation: (i) accounting separation, (ii) 'subsidiarisation' and (iii) ownership separation, ie prohibition of certain business lines. A range of entity arrangements have resulted along a spectrum from narrow trading entities with correspondingly broad deposit-taking entities through to broad trading entities with correspondingly narrow deposit entities: European Commission, 'Impact Assessment' (Working Document, 29 January 2014) <http://eur-lex.europa.eu/legal-content/EN/TXT/DOC/?uri=CELEX:52014SC0030\&from=EN>. 
risk of taxpayer exposure to bank losses..$^{54}$ The changes should also prevent the considerable public subsidies enjoyed by banks, such as central bank lending facilities and deposit guarantee schemes, from applying beyond traditional banking which supports the real economy. Moreover, the changes might reduce the moral hazard contributing to riskier securities and proprietary trading: 'By more credibly restricting the ambit of tax-payer funded creditor guarantees to depositors it could furnish these benefits more efficiently and cheaply from a social cost perspective'. ${ }^{5}$ While some of these reforms, such as those in the US Dodd-Frank Act', ${ }^{56}$ have been enacted, many of its supporting rules and regulations have yet to be finalised, resulting in ongoing implementation delays. ${ }^{57}$

Although there is little discussion of professionalism as a concept in these initiatives, ${ }^{58}$ these are the structural platforms upon which professionalism must operate. The reforms should reduce the scale and complexity of banks, improve transparency and render banks easier to manage through individual and collective decision-making. The structural separation should reduce the scope for conflicts of interest and reduce aggressive risk cultures in ordinary banking.

However, there remains a widespread sense internationally among regulators and others that many of the fundamental problems of the banking sector, which delivered the GFC and LIBOR misconduct, remain unresolved despite reforms. These issues were crystallised by Mark Carney, Governor of the Bank of England and Chair of the Financial Stability Board ('FSB'), in a letter to the Group of 20 ('G20') finance ministers and central bank governors in 2015, which drew our attention back to individual motivation and conduct:

The scale of misconduct in some financial institutions has risen to a level that has the potential to create systemic risks. Fundamentally, it threatens to undermine trust in financial institutions and markets, thereby limiting some of the hard-won benefits of the initial reforms ... Enforcement must remain a credible deterrent to misconduct and the FSB will consider the extent to which enhanced co-operation between conduct supervisors and greater consistency in the application of conduct regulations across jurisdictions can improve its effectiveness..$^{59}$

Carney went on to lay out a further agenda of work to reduce the likelihood of misconduct through assessing reforms to risk governance, compensation structures and benchmarks, and by considering ways to improve market structure, standards of practice and incentives for good conduct in financial markets more broadly. ${ }^{60} \mathrm{~A}$ critical point at which to commence these further reforms is the remuneration system of banking. This base is to ensure that incentives and disincentives more closely reflect the longer-run balance between business risks

\footnotetext{
54 Liikanen Report, above n 53; Haldane, above n 42.

55 Julian T S Chow and Jay Surti, 'Making Banks Safer: Can Volcker and Vickers Do It?’(Working Paper No 11/236, International Monetary Fund, November 2011) 4.

5612 USC $\S \S 5301-5641$ (2012).

57 See Oran, above $\mathrm{n} 51$ and accompanying text.

58 See, eg, in the US, the Dodd-Frank Act, 12 USC §§ 5301-5641 (2012); in the UK, the Vickers Report, above n 52, and Financial Services (Banking Reform) Act 2013 (UK); and, in the EU, the Liikanen Report, above n 53.

59 Letter from Mark Carney to G20 Finance Ministers and Central Bank Governors, 4 February 2015, quoted in European Commission, 'European Financial Stability and Integration', above n 47, 171.

60 Ibid.
} 
and rewards, with remuneration deferred in favour of long-term performance rather than awarded for short-term gains. It is to this question of individual remuneration in banking and its challenge to the professionalising of conduct in a regulated context that we now turn.

\section{B Remuneration Reform}

The primacy of sales-driven, ultra-high remuneration as a contributing factor to risky conduct is clear in the evidence from reports of bank behaviour before the GFC, with the highly-geared, performance-oriented and hierarchical character of financial firms focused solely on efficiency and profit-making. Encouraged by individual remuneration linked to sales revenue and bank profits, this culture overwhelmed the older ideas of client and public service, which some parts of banking allegedly once had. This is demonstrated by the KPMG Report on the management of UBS before the financial crisis:

The IB [investment bank] was focused on the maximization of revenue. There appears to have been a lack of challenge on the risk and reward to business area plans within the investment bank at a senior level. UBS's [internal] review suggests an asymmetric focus in the IB Senior Management meetings on revenue and P\&L [profit and loss], especially when compared to discussion of risk issues $\ldots$ it remains the case that bonus payments for successful and senior IB [investment bank] Fixed Income traders, including those in the businesses holding Subprime positions were significant. Essentially, bonuses were measured against gross revenue after personnel costs, with no formal account taken of the quality and sustainability of those earnings. ${ }^{61}$

The 2010 report to UBS shareholders concluded:

Remuneration systems that placed excessive emphasis on the net new money criterion in the cross-border sector, and which excluded risk-allocated costs in connection with financing at the Investment Bank, did not create incentives for sustainable growth. ${ }^{62}$

Such approaches to incentives were widespread in the international banking industry at the time, as the international audit institutions subsequently concluded:

Financial institution compensation practices that reinforced lax underwriting and excessive risk taking has also been a contributor of the financial crisis. Specifically, financial institutions created distorted incentives for employees by rewarding the volume of loan or securitized transaction origination over long-term asset quality. ${ }^{63}$

The Bank of England concluded in the years leading up to the financial crisis that bonus payments more than doubled in the finance and insurance industry, which considerably outpaced growth in gross domestic product in the wider economy. Excessive incentives included rewarding high short-term profits with generous bonuses and encouraging excessive risk-taking that did not consider the

\footnotetext{
61 UBS, ‘Shareholder Report on UBS’s Write-Downs’ (18 April 2008) 34, 42.

62 UBS, 'Transparency Report to the Shareholders of UBS AG' (2010) $60<$ http://www.cdt.ch/files/docs/ 795404f7d134b0f00b061d172c661abf.pdf>.

63 Swedish National Audit Office, 'The Causes of the Global Financial Crisis and Their Implications for Supreme Audit Institutions’ (Report, 2010) [24].
} 
long-term risks created for banks and for wider society. ${ }^{64}$ The Bank of England report outlines how the UK Prudential Regulation Authority's remuneration rules for banks have changed the structure of remuneration in the industry, which supports the direction of the global policy agenda on financial remuneration. Prior to the financial crisis, patterns of bank remuneration showed no restrictions on the size of variable remuneration relative to fixed remuneration, nor were there restrictions on how much of variable remuneration packages were paid out in cash versus non-cash benefits, such as shares. As we have summarised above, performance measures used to determine variable remuneration packages relied heavily on revenue and profit metrics that were not adjusted for the risks taken. There were no regulatory requirements in relation to payment deferral, 'malus' 65 or clawback of variable remuneration paid.

Following the GFC, there was a concerted effort, which still continues, at the international, national and institutional level, to reconceive the remuneration prevailing in the banking sector around principles relating to proper governance of compensation, effective alignment of compensation with risk-taking and effective supervision and engagement by stakeholders. ${ }^{66}$ The International Monetary Fund supported a range of initiatives to introduce bonus clawbacks, longer vesting periods and other arrangements more carefully calibrated towards long-term growth. ${ }^{67}$ The FSB has maintained a review of the compensation practices of significant financial institutions and is committed to enhanced public disclosure and transparency of bank compensation and enhanced supervisory oversight at the national level. ${ }^{68}$ The Dodd-Frank Act ${ }^{69}$ in the US contained key measures giving shareholders 'say on pay' votes, increased disclosure and transparency, and new standards for integrity and accuracy of executive compensation. This included the recovery of excess remuneration and payments based on misreported financial information. The US Federal Reserve reported on the traction of these remuneration reforms including in terms of risk adjustments and deferring payouts at 25 large US banks. ${ }^{70}$

64 Marilena Angeli and Shahzad Gitay, Bank of England, 'Bonus Regulation: Aligning Reward with Risk in the Banking Sector’ (2015) 55 Quarterly Bulletin 322.

65 Where an employee's performance bonus is returned due to the discovery of a defect in their performance.

66 Financial Stability Board, 'FSF Principles for Sound Compensation Practices' (Principles Statement, 2 April 2009) <http://www.fsb.org/wp-content/uploads/r_0904b.pdf>; International Monetary Fund, 'Global Financial Stability Report: Risk Taking, Liquidity, and Shadow Banking: Curbing Excess while Promoting Growth’ (Report, October 2014) ch 3 ('Global Financial Stability Report').

67 Global Financial Stability Report, above n 66, 111-12.

68 Financial Stability Board, 'National Regulation and Supervisory Guidance on Compensation' (Publication, 21 January 2015) <http://www.fsb.org/wp-content/uploads/r_120709.pdf>; Financial Stability Board, 'Implementing the FSB Principles for Sound Compensation Practices and Their Implementation Standards’ (Progress Report No 4, 10 November 2015) <http://www.fsb.org/wpcontent/uploads/FSB-Fourth-progress-report-on-compensation-practices.pdf $>$.

6912 USC $\S \S 5301-5641$ (2012).

70 Board of Governors of the Federal Reserve System, 'Incentive Compensation Practices: A Report on the Horizontal Review of Practices at Large Banking Organizations’ (Report, October 2011). 
In the EU, full implementation ${ }^{71}$ of the proposals emanating from the FSB has been supported by regulators. This includes capping the ratio of variable to fixed compensation at 1:1, which can be increased to 2:1 if approved by a supermajority of at least 66 per cent of shareholders. Bonus, malus and clawback clauses must apply to 100 per cent of variable compensation and at least 40 per cent of each executive's bonus (and 60 per cent of each senior executive's bonus) must be deferred. Detailed disclosure of remuneration practices is required from large institutions with information on the link between pay and performance, and aggregate figures of remuneration. As the EU Directive states:

Remuneration policies which encourage excessive risk-taking behaviour can undermine sound and effective risk management of credit institutions and investment firms. Members of the G-20 committed themselves to implementing the Financial Stability Board (FSB) Principles for Sound Compensation Practices and Implementing Standards, which address the potentially detrimental effect of poorly designed remuneration structures on the sound management of risk and control of risk-taking behaviour by individuals. This Directive aims to implement international principles and standards at [European] Union level by introducing an express obligation for credit institutions and investment firms to establish and maintain, for categories of staff whose professional activities have a material impact on the risk profile of credit institutions and investment firms, remuneration policies and practices that are consistent with effective risk management. ${ }^{72}$

In the UK, the collapse of the Royal Bank of Scotland in 2008 followed immediately upon a reckless highly-incentivised ascent to becoming, by acquisition, the largest bank in the world. This was despite Royal Bank of Scotland and HBOS, which also failed, both receiving substantial regulatory reviews, followed by detailed Parliamentary Treasury Committee inquiries which kept the subject of risk management and executive compensation in the banking sector firmly in public focus. This has continued up to the present. ${ }^{73} \mathrm{~A}$ highlight in this process was a resolute report subsequently published by the 2013 UK Parliamentary Banking Inquiry. ${ }^{74}$ Mandatory rules of the UK Prudential Regulation Authority and the Financial Conduct Authority now require a bonus cap. This sets a maximum variable-to-fixed remuneration ratio of 2:1 and requires shareholder approval. ${ }^{75}$ All variable remuneration should be composed

71 See Directive 2013/36/EU of the European Parliament and of the Council of 26 June 2013 on Access to the Activity of Credit Institutions and the Prudential Supervision of Credit Institutions and Investment Firms, Amending Directive 2002/87/EC and Repealing Directives 2006/48/EC and 2006/49/EC [2013] OJ L $176 / 338$

72 Ibid 345

73 Financial Services Authority, 'The Failure of the Royal Bank of Scotland: Financial Services Authority Board Report' (Report, December 2011); Treasury Committee, The FSA's Report into the Failure of RBS, House of Commons Paper No 640, Session 2012-2013 (2012); Prudential Regulatory Authority and Financial Conduct Authority, 'The Failure of HBOS Plc (HBOS): A Report by the Financial Conduct Authority (FCA) and the Prudential Regulation Authority (PRA)' (Report, November 2015); Treasury Committee, Review of the Reports into the Failure of HBOS, House of Commons Paper No 582, Session 2016-2017 (2016).

74 Changing Banking for Good vol II, above n 4.

75 Exercising powers under the Financial Services and Markets Act 2000 (UK), enforced by the Financial Conduct Authority and to be applied to all major risk takers including senior managers in large financial institutions from 2016: see Prudential Regulation Authority and Financial Conduct Authority, 'Strengthening the Alignment of Risk and Reward: New Remuneration Rules' (Policy Statement No PRA 
of 50 per cent cash and 50 per cent non-cash, and only 40 per cent of all variable remuneration should be paid up-front with 60 per cent deferred. All deferred remuneration, which has not yet vested, can be subjected to malus to take account of instances of misconduct, risk management failings or downturn in financial performance. ${ }^{76}$ The Australian Prudential Regulation Authority has confined itself to including remuneration of senior managers in a series of disclosures regarding capital adequacy and risk management. ${ }^{77}$ In relation to sales of financial products with advice, legislation in Australia has banned conflicted remuneration structures, including commissions and volume-based payments, ${ }^{78}$ though there are wide exemptions for simple banking and insurance products which staff at front counter are incentivised to sell. ${ }^{79}$

In principle, this raft of international reforms might provide a more stable incentive structure that could be adapted to stress greater responsibility in decision-making, though at this stage there is little evidence of any significant reductions in the overall level of executive reward in banking. ${ }^{80}$ However, even in this more reflective phase of banking, the language and critique concentrates on damage to the profitability and reputation of the bank as an entity, its employees and its shareholders. Nothing in the assessments from the experts or the banks, set out above, contains thinking about a duty to the client. ${ }^{81}$ Likewise, there is no discussion of bankers having a duty to act in the public interest and how banking might have any wider social utility or confer a public benefit. ${ }^{22}$ Rather, when it became clear in 2012 that traders at leading international banks were centrally involved with fixing the LIBOR, the facts were clear that the manipulation was designed to benefit the bank and themselves.

In his discussion of the development of professional ethical norms, Breakey presents the idea of 'spoilers' and 'facilitators' of that development and their importance in 'the construction, reform or continuance of a professional ethos' ${ }^{83}$ It is tempting to conclude that, on the fragile and unpropitious terrain of banking

PS12/15, FCA PS15/16, June 2015) <http://www.bankofengland.co.uk/pra/Documents/publications/ ps/2015/ps1215.pdf $>$.

76 Ibid 331.

77 Australian Prudential Regulation Authority, Prudential Standard APS 330: Public Disclosure, APS 3301, June 2013 <http://www.apra.gov.au/adi/PrudentialFramework/Documents/APS-330-June-2013.pdf>.

78 Corporations Act 2001 (Cth) pt 7.7A div 2 sub-div C, as amended by Corporations Amendment (Future of Financial Advice) Act 2012 (Cth) sch 1 item 1 and Corporations Amendment (Further Future of Financial Advice Measures) Act 2012 (Cth) sch 1 item 33. See also Australian Securities and Investment Commission ('ASIC'), FOFA - Background and Implementation (23 March 2016) <http://asic.gov.au/ regulatory-resources/financial-services/future-of-financial-advice-reforms/fofa-background-andimplementation/>.

79 Corporations Act 2001 (Cth) ss 963B-963D. See also Clancy Yeates, 'Union Calls for Consistency on Advice Rules’, Sydney Morning Herald (Sydney), 10 September 2016, 3.

80 Global Financial Stability Report, above n 66, 115.

81 Cf Greg Smith, Why I Left Goldman Sachs: A Wall Street Story (Grand Central Publishing, 2014) 296299.

82 Adair Turner, Between Debt and the Devil: Money, Credit and Fixing Global Finance (Princeton University Press, 2016); Paul Volcker, 'The Only Useful Thing the Banks Have Invented in 20 Years Is the ATM', New York Post (online), 13 December 2009 <http://nypost.com/2009/12/13/the-only-thinguseful-banks-have-invented-in-20-years-is-the-atm/> . 
on which we transplant professionalism, remuneration remains a 'spoiler' for which there are few responses. It is often argued that remuneration in banking is a decisive marker of commercial norms to which professionalism is thought to be an alternative. However, as the other articles in this Issue reveal, ${ }^{84}$ in remuneration, as in other areas, the differences between business and professions are not always as great as portrayed. While hourly fees still govern much, if not most, professional remuneration and are sometimes held up as the antidote to incentivised remuneration in business, ${ }^{85}$ the billable hour too has its deficiencies as a prompt to professional standards and values. ${ }^{86}$

Moreover, while it is true that in the professions those who serve best may earn high fees, those fees can never be the central justification of a profession. ${ }^{87}$ By comparison, models of remuneration in banking directly link extremes in ultra-high remuneration to sales-driven revenue and profits of entities. It is difficult to see how these models are compatible with a duty to put clients' interests first or to act in the public interest. ${ }^{88}$ While there is no doubt that changing fee models are a challenge for professional practice, the fees are simply not as great (and potentially distorting) in the professions as they are in banking. Second, professional fees still relate to advice and not to profit from a bank's own competing proprietary deals, ${ }^{89}$ which we discuss below. The questions we now turn to are whether and to what degree it is possible that banking might adopt the central duties and structures of the professions, despite the incentives of remuneration and the relative anonymity of decision-making and conduct in large complex organisations. How might professional duties spur ideals over interests ${ }^{90}$ How might they improve decisions and conduct where regulation has in part failed to do so?

\section{BANKING AND THE PUBLIC INTEREST}

As the earlier articles in this Issue have established, professional logic holds that the relative independence and privilege of associational regulation and, by extension, the professions, are part of a notional 'regulative bargain' with government and society. In exchange for autonomy, it is argued, the professions

84 See especially Rogers, Kingsford Smith and Chellew, above n 21.

85 For example, commissions, volume over-riders or success-based bonuses.

86 Michael Kirby, 'Billable Hours in a Noble Calling?’ (1996) 21 Alternative Law Journal 257; Iain Campbell and Sara Charlesworth, 'Salaried Lawyers and Billable Hours: A New Perspective from the Sociology of Work’ (2012) 19 International Journal of the Legal Profession 89.

87 Charles Sampford, 'Financial Integrity and Professionalization: Towards Financial Innovation You Can Trust' (Working Paper, Financial Integrity Conference, University of Melbourne, September 2011), (copy kept on file with author).

88 Changing Banking for Good vol II, above n 4, ch 8; William C Dudley, 'Enhancing Financial Stability by Improving Culture in the Financial Services Industry’ (Speech delivered at the Conference on Reforming Culture and Behavior in the Financial Services Industry, Federal Reserve Bank of New York, New York City, 20 October 2014).

89 Smith, above n 81, 234.

90 Mary G Condon, Making Disclosure: Ideas and Interests in Ontario Securities Regulation (University of Toronto Press, 1998). 
and professionals have a duty to support the important institutions associated with the practice of their profession.

To be clear, we do not persist with the argument that banking should identify and commit to a general public good only because of a blind adherence to professional logic. Rather, we agree with Boatright's comments (considered further below) in relation to oaths: 'oaths in their most common uses are largely affirmations of a commitment to service that are embedded in a larger institutional framework that is absent in banking'. ${ }^{91}$ Our argument here is that the identification of a 'larger institutional framework' ${ }^{92}$ helps motivate individual commitment. If finance is to change into something more beneficial than risky business linked to high remuneration and profitability, a commitment is required by both the entity and cognitively and behaviourally by individual bankers. We assert that oaths, codes of conduct and practice, and extensions of professional frameworks, such as Sampford's ethical integrity systems, ${ }^{93}$ can help motivation by crystallising these 'larger institutional frameworks'.

There is practical, experiential support for this view from banking itself. In 2013, the Salz Review ${ }^{94}$ examined the conduct of Barclays Bank in the setting of LIBOR, the first bank identified as having manipulated this globally influential interest rate. ${ }^{95}$ This conduct resulted in Barclays ultimately having to pay fines of close to half a billion US dollars. ${ }^{96}$ The Review concluded that poor conduct could thrive in a group where 'there was no sense of common purpose ... And across the whole bank, there were no clearly articulated and understood shared values' ${ }^{97}$ We suggest there is considerable overlap between Boatright's 'larger institutional frameworks' and the Salz Committee's 'sense of common purpose ... and shared values'. The absence of purpose leaves room for the development

91 Boatright, above n 2, 141.

92 Ibid.

93 Sampford, above n 87, 9-10.

94 A review established by Sir David Walker, the Chair of Barclays Bank, as an independent inquiry lead by Anthony Salz, a pre-eminent corporate lawyer: Anthony Salz, 'Salz Review: An Independent Review of Barclays’ Business Practices’ (Report, Barclays Bank, April 2013)

<http://online.wsj.com/public/resources/documents/SalzReview04032013.pdf> ('Salz Review'). See also above $n 9$ and accompanying text.

95 The terms of reference and program of work included investigation of the organisation's values and principles and its practices or culture: see Salz Review, above n 94, appendix A.

96 Barclays Bank ultimately paid fines of US\$200 million, US\$180 million and £59.5 million: Commodity Futures Trading Commission, ‘CFTC Orders Barclays to Pay \$200 Million Penalty for Attempted Manipulation of and False Reporting Concerning LIBOR and Euribor Benchmark Interest Rates’ (Press Release, PR6289-12, 27 June 2012) <http://www.cftc.gov/PressRoom/PressReleases/pr6289-12>; US Department of Justice, 'Barclays Bank PLC Admits Misconduct Related to Submissions for the London Interbank Offered Rate and the Euro Interbank Offered Rate and Agrees to Pay \$160 Million Penalty’ (Press Release, 27 June 2012) <https://www.justice.gov/opa/pr/barclays-bank-plc-admits-misconductrelated-submissions-london-interbank-offered-rate-and>; Financial Services Authority, 'Barclays Fined $£ 59.5$ Million for Significant Failings in relation to LIBOR and EURIBOR’ (Press Release, FSA/PN/070/2012, 27 June 2012) <http://www.fsa.gov.uk/library/communication/pr/2012/070.shtml>.

97 Salz Review, above n 94, 6, quoted in David T Llewellyn, Roger Steare and Jessica Trevellick, Virtuous Banking: Placing Ethos and Purpose at the Heart of Finance (ResPublica, 2014) 11

<http://www.respublica.org.uk/wp-content/uploads/2014/07/ueq_Virtuous-Banking-Final-new.pdf>. 
of unhealthy cultures and sub-cultures such as that which surrounded the manipulation of LIBOR, not only at Barclays but across the sector..$^{98}$

The obvious responses to advocacy of a beneficial or public interest purpose for banking are, firstly, that even traditional professions articulate and realise a public interest duty imperfectly. Secondly, the evidence of greater ethical motivation derived from shared purpose or values is questionable and related to the equally contestable assertion that the professions are more ethical than occupations. Before turning to the question of what banking might adopt as its public interest purpose were it to professionalise, we address these two objections.

As acknowledged in the opening article in this Issue ${ }^{99}$ traditional professions have undergone drastic changes and many of their organisations are adopting both the logic and arrangements of business: 'Professional identities are increasingly framed around logics of efficiency and commerce, which have displaced traditional logics of ethics and public service'. ${ }^{100}$ Yet, accepting the views of writers who have emphasised, following Larson, the self-seeking inherent in the market and status 'projects' of professional advancement, ${ }^{101}$ the public interest remains one of the 'normative, coercive, and mimetic pressures' of professionalism. ${ }^{102}$ Further, because government and the public 'are not totally gullible' ${ }^{103}$ and professional legitimacy is tied to the regulative bargain, the public interest cannot be merely a self-serving ideology, even if the commitment to it is not entirely enacted. Indeed, one problem with the market control critique is that it obscures the fuller roles professions play in social life. ${ }^{104}$ Halliday rejects this market paradigm because it fails to go 'beyond monopoly' to capture the broader set of motivations besides self-interest that guide professional action ${ }^{105}$ and so

98 Other banks prosecuted or fined over the LIBOR scandal have included UBS, which paid fines totalling around US \$1.5 billion, Deutsche Bank, Société Générale, Royal Bank of Scotland, JP Morgan and Citigroup, and in Australia, ASIC has obtained fines totalling over AU \$3.6 million from BNP Paribas, Royal Bank of Scotland and UBS for potential manipulation of the Australian equivalent of the LIBOR, the Bank Bill Swap Rate: 'UBS Fined \$1.5bn for Libor Rigging', British Broadcasting Corporation (online), 19 December 2012 <http://www.bbc.com/news/business-20767984>; European Commission, 'Amended - Antitrust: Commission Fines Banks €1.49 Billion for Participating in Cartels in the Interest Rate Derivatives Industry’ (Press Release, IP/13/1208, 4 December 2013); ASIC, ‘ASIC Accepts Enforceable Undertaking from BNP Paribas’ (Media Release, 14-014MR, 28 January 2014) $<$ http://asic.gov.au/about-asic/media-centre/find-a-media-release/2014-releases/14-014mr-asic-acceptsenforceable-undertaking-from-bnp-paribas/>; ASIC, 'ASIC Accepts Enforceable Undertaking from the Royal Bank of Scotland’ (Media Release, 14-169MR, 21 July 2014); ASIC, 'ASIC Accepts Enforceable Undertaking from UBS’ (Media Release, 13-366MR, 23 December 2013).

99 See Rogers, Kingsford Smith and Chellew, above n 21.

100 Daniel Muzio, David M Brock and Roy Suddaby, 'Professions and Institutional Change: Towards an Institutionalist Sociology of the Professions’ (2013) 50 Journal of Management Studies 699, 700.

101 See, eg, Richard L Abel, The Legal Profession in England and Wales (Basil Blackwell Publishers, 1988); Richard L Abel, English Lawyers between Market and State: The Politics of Professionalism (Oxford University Press, 2003).

102 Muzio, Brock and Suddaby, above n 100, 702.

103 Keith M Macdonald, The Sociology of the Professions (Sage Publications, 1995) 35.

104 Muzio, Brock and Suddaby, above n 100, 701.

105 Terence C Halliday, Beyond Monopoly: Lawyers, State Crises, and Professional Empowerment (University of Chicago Press, 1987). 
account for the normative value of professionalism. ${ }^{106}$ While accepting Larson's insights about some of the primary means by which professions acquire and maintain control over their definition as professions, ${ }^{107}$ professionalism as an appeal to quality, social trusteeship and public interest remains part of their means of control. Indeed, it is because professions have historically tried and still try to give their activities a particular normative value beyond their technical requirements ${ }^{108}$ that they have attracted interest in diagnosing the failure of values and governance in banking. Moreover, we must expect this public ethos of professions and, for that matter, banking. We are not about to 'fix our heart valves ourselves, invest our money without any advice, sue a corporation that has wronged us without any professional representation' ${ }^{109}$ Despite the changes and critique, then, we continue to expect professions to deal with 'the complex issues that advanced modernity hands our way'. ${ }^{110}$

The second objection is scepticism that Boatright's 'larger institutional frameworks' and the Salz Committee's 'sense of common purpose ... and shared values' motivate professional or prosocial behaviour. More specifically, it questions whether intrinsic ethical attitudes, through 'professional' beliefs, values, education and socialisation, or extrinsically motivated ethical attitudes, through professional codes, regulation and other controls, actually link to better, prosocial behaviour. Do these features of professionalism make professionals act in less selfish, less profit-oriented ways than non-professionals? Or are their public interests claims, and even beliefs and motivations, rhetorical justifications or, less cynically, self-beliefs that do not connect to routine ethical action?

Assessing this issue represents an immense conceptual challenge, particularly without an obvious comparator control group to study. We cannot assess whether, for example, doctors would act differently without their Hippocratic Oath or disciplinary bodies. There have been very few comparative studies between professions and non-professions, though there are individual studies on specific behaviour. For example, one study demonstrated that lawyers are less willing to lie in negotiations than business executives are. ${ }^{111}$ While not comparative, there is a deep vein of research to suggest that economics and finance students, as future bankers, become less public-minded over the course of their studies. ${ }^{12}$ It indicates that immersion in the study of economics, with its conceptual models based on the idea of rationally self-interested homo

106 Muzio, Brock and Suddaby, above n 102, 703.

107 Professionalism is not inherent to any occupation, but is instead a means of organising and controlling an occupation: ibid 702.

108 Ibid 713.

109 Kevin T Leicht, 'Market Fundamentalism, Cultural Fragmentation, Post-Modern Skepticism, and the Future of Professional Work' (2016) 3 Journal of Professions and Organization 103, 13-14.

110 Ibid.

111 Andreas Feidakis and Aspasia Tsaoussi, 'Competitiveness, Gender and Ethics in Legal Negotiations: Some Empirical Evidence’ (2009) 14 International Negotiation 537, 558.

112 Linda K Treviño, Gary R Weaver and Scott J Reynolds, 'Behavioral Ethics in Organizations: A Review' (2006) 32 Journal of Management 951, 967. 
economicus, induces behaviour away from cooperation and altruism. ${ }^{113}$ Similarly, Bandura includes the use of euphemistic or 'sanitizing' language as a key 'manoeuvre' in moral disengagement. ${ }^{114}$ Nonetheless, there have been similar findings for legal education and law students as professionals. ${ }^{115}$

To make matters more difficult, we are arguing for professional beliefs and practices knowing

there are a number of competing and overlapping frameworks for deciding what the standard [of ethical behaviour] is:

- have key rules or duties been adhered to (akin to either deontological or compliance approaches)?

- are the consequences of actions ethical (usually seen as a utilitarian approach);

- does character, experience and thoughtful reflection on experience suggest the approach is ethical (broadly, the virtue ethics approach)?

- is a decision sufficiently informed by one's relationships with all interested parties (the relational approach) [or stakeholder approach, we discuss later]? and,

- a combination of all or some of the above in the light of a particular ethical problem's context (the contextual approach). ${ }^{116}$

Again to complicate the issue, ethics research is problematic because it tends to rely on self-reporting and ethics is one area of research in which the tendency to present an idealised self is high. Furthermore, research has demonstrated different levels of ethicality between professions and within them. Context plays a considerable and increasing role over the practices of professionals, who interpret and apply their professional codes differently. ${ }^{117}$ For example, Moorhead and Hinchley have shown how corporate lawyers in particular understand ethics in minimal, 'so long as not illegal or dishonest' terms, with a strong client-

113 Ibid, citing Robert H Frank, Thomas Gilovich and Dennis T Regan, 'Does Studying Economics Inhibit Cooperation?’ (1993) 7 Journal of Economic Perspectives 159; Robert H Frank, Thomas D Gilovich and Dennis T Regan, 'Do Economists Make Bad Citizens?' (1996) 10 Journal of Economic Perspectives 187; cf Anthony M Yezer, Robert S Goldfarb and Paul J Poppen, 'Does Studying Economics Discourage Cooperation? Watch What We Do, Not What We Say or How We Play’ (1996) 10 Journal of Economic Perspectives 177.

114 Albert Bandura, 'Moral Disengagement in the Perpetration of Inhumanities' (1999) 3 Personality and Social Psychology Review 193.

115 Although, the situation is more complex than the diminished ethicality effect: see Kennon M Sheldon and Lawrence S Krieger, 'Does Legal Education Have Undermining Effects on Law Students? Evaluating Changes in Motivation, Values, and Well-Being' (2004) 22 Behavioral Sciences and the Law 261. Indeed, there is evidence that law school both strengthens and weakness ethical identity: Richard Moorhead et al, 'The Ethical Identity of Law Students' (2016) 23 International Journal of the Legal Profession 235. There is also evidence that legal education - and practice - have a neutral impact on the values informing ethical decision-making and decision-making here must be seen as deriving from a wide set of ethical values: Adrian Evans and Josephine Palermo, 'Zero Impact: Are Lawyers' Values Affected by Law School?' (2005) 8 Legal Ethics 240.

116 Richard Moorhead et al, 'Designing Ethics Indicators for Legal Services Provision’ (Working Paper No 1, Centre for Ethics and Law, September 2012) 20. See at 22-4, 28-33 for reasons why ethics research is difficult and therefore requires a range of methods.

117 For the legal profession example, see Leslie C Levin and Lynn Mather (eds), Lawyers in Practice: Ethical Decision Making in Context (University of Chicago Press, 2012). 
interest focus. ${ }^{118}$ There is variability in individual values too in law school, some of which trace to gender and career intentions. ${ }^{119}$ Perhaps as some indication that professionals are more ethical than banker-types, there is strong evidence that law students with 'professional' career aspirations are more orientated towards work that primarily deals with people rather than money ${ }^{120}$ and have stronger 'moral identities', than those intending to pursue business law. ${ }^{121}$

At its core, the issue remains whether or not our beliefs and motivations affect our behaviour. The research on moral behaviour shows that it is made up of awareness, analysis, motivation and action. ${ }^{122}$ This framework has been challenged by more recent research which shows that ethical decision-making is often automatic and innate. ${ }^{123}$ However, this earlier and continuing strand of research has demonstrated that certain characteristics of moral issues affect the process of ethical decision-making - most decisively, how it is framed and analysed. These qualities include the magnitude of the consequences, social consensus dimensions, ${ }^{124}$ the presence of a moral language in that context, ${ }^{125}$ and whether the individual has developed a moral identity from their moral (here, professional) beliefs. ${ }^{126}$ Motivation is then crucial for all moral decision-makers, including professionals who can be aware and engage in moral reasoning and yet not feel obliged to act ethically.

There are reasons to believe that professionalism has certain positive effects or has the potential to have positive effects on action. Professionalism comprises a set of beliefs, language and practices that defines membership. It allows the possibility, then, for moral issues to involve a public interest language and social consensus and sanctions, through leadership, community, celebration and discipline, and therefore for higher ethical behaviour. Professionalism is an interpretive frame that includes ethical principles and considerations. As the codes, cases and educational materials attest, these centre on honesty, trust, civility and competence. They also extend to the development of expert knowledge and institutional infrastructure, pro bono work, and reform. ${ }^{127}$ These

118 Richard Moorhead and Victoria Hinchly, 'Professional Minimalism? The Ethical Consciousness of Commercial Lawyers’ (2015) 42 Journal of Law and Society 387.

119 Moorhead, above n 115; Adrian Evans and Josephine Palermo, ‘Australian Law Students' Perceptions of Their Values: Interim Results in the First Year - 2001 - of a Three-Year Empirical Assessment’ (2002) 5 Legal Ethics 103.

120 This distinction was made by a senior barrister to Rogers during her doctoral research.

121 Moorhead et al, 'The Ethical Identity of Law Students', above n 115.

122 James Rest, Muriel Bebeau and Joseph Volker, ‘An Overview of the Psychology of Morality’ in James R Rest (ed), Moral Development: Advances in Research and Theory (Praeger Publishers, 1986) 1; James R Rest, 'Background: Theory and Research’ in James R Rest and Darcia Narváez (eds), Moral Development in the Professions: Psychology and Applied Ethics (Lawrence Erlbaum Associates, 1994).

123 Jonathan Haidt, The Righteous Mind: Why Good People Are Divided by Politics and Religion (Pantheon Books, 2012) pt 1. See, eg, Robert A Prentice, 'Behavioral Ethics: Can It Help Lawyers (and Others) Be Their Best Selves’ (2015) 29 Notre Dame Journal of Law, Ethics and Public Policy 35, 58 n 124.

124 Treviño, Weaver and Reynolds, above n 112, 954.

125 Kenneth D Butterfield, Linda Klebe Treviño, and Gary R Weaver, 'Moral Awareness in Business Organizations: Influences of Issue-Related and Social Context Factors’ (2000) 53 Human relations 981.

126 Treviño, Weaver and Reynolds, above n 112, 962.

127 Rogers observed in her doctoral study of English barristers active avoidance of conflicts of interest and sharp practices, along with 'moral minimalism'. 
features exist in other occupations, however not as much as they do for professions, even though some of these are under immense strain. Professionalism makes engagement more likely, or disengagement less likely, because it involves a strong language of responsibility to an institution. What is at stake if the members disengage with moral duties is salient. As mentioned, these factors are associated with ethical behaviour. ${ }^{128}$ In addition, if people are able to practise ethical behaviour, it is more likely to be part of their identity, which in turn supports the behaviour ${ }^{129}$ and, by extension, their institutions. ${ }^{130}$

In the next section, we focus on two practices or reifications of this public interest purpose and commitment: the professional oath and codes of professional conduct.

\section{A Professional Oaths}

Our question is, then, what important institution conferring public benefit might bankers agree or promise to uphold above all else, to earn legitimacy and develop self-consciousness as a profession? What could banking promise to deliver in order to come to a supposed regulative bargain with the state of the type foundational to traditional professions, allowing it to earn at least a degree of regulatory autonomy? Searching for such a public interest or purpose we compare three new bankers' oaths recently formulated: the Dutch bankers' oath, ${ }^{131}$ which since 1 April 2013 has been part of the Dutch Wet op het financieel toezicht [Financial Supervision Act] (Netherlands) stb-2006-475; a British one proposed and promoted by ResPublica, a non-party political public policy research organisation which released the oath in 2014 though it has not been

128 Treviño, Weaver and Reynolds, above n 112.

129 Ibid 963.

130 For an example of how routine civility supports the legal profession and its commitment to justice, see James Allsop, 'Civility, Reason, Fairness and Justice, and the Law' [2014] Federal Judicial Scholarship 1.

131 This oath, which enjoys legislative backing, originated in the Dutch Banking Association Banking Code 2010. Parts of the Banking Code were converted into legislative requirements after a 2013 review: Herman Wijffels et al, 'Towards a Serviceable and Stable Banking System' (Report, Commission on the Structure of Dutch Banks, June 2013) ('Wijffels Review'). In 2014, the Dutch Banking Association produced a document which includes not only a social charter, banking code and rules of conduct, but also a 'Bankers' Oath', which provides:

I swear/promise within the limits of the position I hold at any time in the banking sector:

- I will execute my function ethically and with care;

- I will draw a careful balance between the interests of all parties associated with the business, being the customers, shareholders, employees and the society in which the business operates;

- When drawing that balance, I will make the customers' interests central;

- I will comply with the laws, regulations and codes of conduct that apply to me;

- I will keep confidential that which has been entrusted to me;

- I will not abuse my knowledge;

- I will act openly and accountably and I know my responsibility to society;

- I will make every effort to retain and improve trust in the financial sector.

So help me God/This I declare and promise.

Dutch Banking Association, 'Oath and Discipline' (Dutch Banking Association trans) (Publication, 14 October 2014) [trans of: Bankierseed] <https://www.nvb.nl/publicaties/gedragscodes/1400/bankierseedbankers-oath-toekomstgericht-bankieren.html>. 
officially adopted, ${ }^{132}$ which we call the 'ResPublica oath'; and, thirdly, the Australian Banking and Finance Oath developed by a specially formed civil society organisation, to which signatories subscribe. ${ }^{133}$ We have included the texts of these oaths in the footnotes. We are not so naive as to think that oaths can so change behaviour as to hold back the tide of poor banking and financial behaviour single-handedly. However, we do think that reviewing bankers' oaths may serve to make transparent and crystallise what bankers think are the core purposes of their occupation, including public ones.

Oaths are closely connected in nature and effect to the professional code of conduct, but tend to be a more concentrated statement of values than a code. An oath is also sworn or affirmed, a performed commitment, which gives an oath a greater moral weight. ${ }^{134}$ The most famous oath is that of doctors in which they promise to 'serve humanity with the utmost respect for human life, even under threat'. ${ }^{135}$ Lawyers promise to do likewise through the true and honest

132 ResPublica aims to develop bold solutions to enduring social and political problems 'which prioritise the need to recover the language and practice of the common good': Llewellyn, Steare and Trevellick, above n 97. The oath and accompanying justification are set out in Llewellyn, Steare and Trevellick, above n 97, 14 which provides:

I swear to fulfil, to the best of my ability and judgement, this covenant:

I will do my utmost to behave in a manner that prioritises the needs of customers. It [is] my first duty to provide an exemplary quality of service to my customers and to exhibit a duty of care above and beyond what is required by law.

I will apply myself to ensuring that the work that I perform is in line with values that engender the responsible creation of value. It is my duty to conduct my business in an ethical manner and to ensure that my actions impact positively on the wellbeing of people both inside and outside my enterprise.

I will confront profligacy and impropriety wherever I encounter it, for the conduct of bankers can have dramatic consequence for society. I will remember that I remain a member of society, with special obligations to the financial security and wellbeing of my customers, their families and the communities they reside in.

If I do not violate this oath, may I benefit from the prosperity that comes from serving customers well. May I always act so as to preserve the finest traditions of my calling and may I long experience the joy that comes from supporting the needs of society.

This oath I make freely, and upon my honour.

133 See The Banking and Finance Oath, The Oath (2015) <http://www.thebfo.org/The-Oath/Mission-andobjectives>:

Trust is the foundation of my profession

I will serve all interests in good faith

I will compete with honour

I will pursue my ends with ethical restraint

I will help create a sustainable future

I will help create a more just society

I will speak out against wrongdoing and support others who do the same

I will accept responsibility for my actions

My word is my bond.

134 Daniel P Sulmasy, 'What Is an Oath and Why Should a Physician Swear One?' (1999) 20 Theoretical Medicine and Bioethics 329, 329; Boatright, above $\mathrm{n} 2$.

135 See, eg, the World Medical Association’s Declaration of Geneva, a modern version of the Hippocratic Oath, which the Australian Medical Association adopted in 2006: Australian Medical Association, 'AMA Adopts WMA Declaration of Geneva’ (Press Release, 28 September 2006) <https://ama.com.au/media/ ama-adopts-wma-declaration-geneva>. 
administration of justice and the rule of law. ${ }^{136}$ Engineers too promise to hold paramount the safety, health and welfare of the public. ${ }^{137}$ The professional ceremonial oath or affirmation is sworn in public before their peers by newly minted members upon entry to the profession. This aspect of the professional promise may be pursued in professional activities outside a practitioner's immediate service to patients or clients, such as in promoting improvements to public health or in law reform or as an engineer working for a more sustainable use of energy. But a professional might also discharge this public interest duty in a quotidian way, by true and honest practice of their profession in the light of its values as an institution, to the best of their knowledge, skill and ability. As Twining has argued, good 'down to earth' technical lawyers who serve their clients faithfully and skilfully also promote and preserve the socially important institutions of the administration of justice and the rule of law. Lawyers (and other professionals) as 'plumbers' can give valuable service to the public interest even though they might not be in the limelight like the lawyer-statesman 'Pericles'. ${ }^{138}$

There are a number of aspects in which the oaths, introduced above, depart from the promises of a traditional professional. There is in the Dutch oath an acknowledgement that a banker will 'know [their] responsibility towards society' and in the ResPublica oath an affirmation that 'I will remember that I remain a member of society with special obligations to the financial security and wellbeing of my customers, their families and the communities they reside in' ${ }^{139}$ The Australian Banking and Finance Oath requires the swearer to promise: 'I will help create a sustainable future; I will help create a more just society' and the associated guidance suggests that 'justice' means essentially 'fairness'. ${ }^{140}$ While these aspirations are well intended they are both too broad and too narrow. They are too broad because they do not specify what the banking and finance institution is and what it can actually do for the greater good, although this is a criticism which can also be made of some professional oaths including law. Rather they opt for grand commitments such as to 'create a more just society' ${ }^{141}$ or that 'I will remember that I remain a member of society with special

136 See, eg, the oath of the lawyer entering practice in NSW:

I, (name) of (address) do swear that ... I will truly and honestly conduct myself in the practice of a legal practitioner of the Supreme Court of New South Wales and I shall faithfully serve as such in the administration of the laws and the usages of that State according to the best of my knowledge, skill and ability.

Supreme Court Rules 1970 (NSW) sch F Form 70AA.

137 Likewise, engineers in many engineering associations take an oath. For example, members of the American Society of Civil Engineers take an oath to uphold their Code of Ethics, which includes a promise to 'hold paramount the safety, health and welfare of the public and shall strive to comply with the principles of sustainable development in the performance of their professional duties': American Society of Civil Engineers, Code of Ethics (23 July 2006) <http://www.asce.org/code-of-ethics/>. William Twining, Law in Context: Enlarging a Discipline (Oxford University Press, 1997) 64-65.

139 Llewellyn, Steare and Trevellick, above n 97, 14.

140 The guidance to the promise emphasises the connection between justice and fairness: The Banking and Finance Oath, above n 133.

141 Ibid. 
obligations'. ${ }^{142}$ They are also indefinite because, with the exception of the Australian oath, they are not expressed in the language of a commitment to positive personal action.

These oaths are at the same time too narrow and self-serving because, when they do express their purpose and commitment to a version of the public good, it is subject to the primacy of client obligation ${ }^{143}$ or sometimes to the banking enterprise itself. The latter is true of the ResPublica promise to engage in the 'responsible creation of value'. All three oaths make the duty to the customer paramount and the Dutch one also provides: 'I will make every effort to retain and improve trust in the financial sector'. In effect, this formulation swears allegiance not to the public interest or public financial welfare, but to the financial-economic concept of 'confidence' which is the (hoped for) product of 'trust' and part of the 'financial sector' itself. This injects a goal, without identifying for whom 'trust' and 'confidence' is to be enhanced, why and at what cost. Was something like 'confident and informed participation of investors and consumers' ${ }^{144}$ intended? Or is it 'business confidence' in the sense of market buoyancy or 'irrational exuberance' that is meant? Does it signify 'market confidence' in the sense of an absence of fraud, insider activity or market manipulation? However, not all of these types of 'confidence' are something to 'preserve and enhance': 'irrational exuberance' can be dangerous to the financial system. ${ }^{145}$

Moreover, if 'market confidence' means simply the absence of fraud or other illegality, then the Dutch oath adds very little beyond ritual and symbolics, ${ }^{146}$ for obeying the law is the baseline requirement of all citizens, not the higher duty of professionals. By turning a market objective into a supposed professional ideal, the Dutch oath loses sight of the purpose of professional duties being to confer a humanistic good. It should be pointed out that these criticisms that oaths are primarily for the benefit of the professional group itself have been made of traditional professional oaths. ${ }^{147}$

Next, all these are oaths made by professionals personally: 'a commitment to be a certain kind of person for other persons'. ${ }^{148}$ They are not made by professional entities or firms, though Dutch banks are required to ensure that all their employees swear or affirm the Dutch oath. The individual quality is a core part of professional integrity and collegiality, since the oath marks out who is

142 Llewellyn, Steare and Trevellick, above n 97.

143 The ResPublica oath states: 'It is my first duty to provide an exemplary quality of service to my customers': ibid. The Dutch oath states that 'I will make the customer's interests central': Dutch Banking Association, above n 131.

144 This is one of the express objectives of the Australian Securities and Investments Act 2001 (Cth): at s 1(2)(b). The Corporations Act 2001 (Cth) s 760A(a) states a similar objective for its Chapter 7 financial markets and services regime.

145 Robert J Shiller, Irrational Exuberance (Princeton University Press, 2000) xi-xvi.

146 Likewise, the British and Australian oaths add nothing further when oath takers simply agree to uphold the law.

147 Kim Economides and Justine Rogers, 'Preparatory Ethics Training for Future Solicitors' (Report, The Law Society [of England and Wales], March 2009) <https://ore.exeter.ac.uk/repository/bitstream/ handle/10036/64973/TLS\%20Ethics\%20Report.pdf?sequence=1\&isAllowed=y > 32-3. Sulmasy, above n 134, 333. 
part of the community on a broader scale than employment in an entity or sector. In this way, professions have given an unequivocal answer to the question often raised in regulatory literature as to whether it is more effective to regulate through an individual or firm obligation: ${ }^{149}$ professions impose obligations on individuals. However, as other articles in this Issue demonstrate, ${ }^{150}$ the professional firm is increasingly the central site for developing and maintaining professional identity and practice, and so their commitment to the wider public interest is vital too.

\section{B Codes of Conduct}

One of the difficulties of professionalising banking discussed by the UK Parliamentary Banking Inquiry is that of forging shared purpose and identity due to the absence of core knowledge, education and training. A related difficulty also discussed by the Inquiry is in developing a common banking code of practice and ethics as another spur towards shared identity and professionalisation. In Britain, there are many codes of conduct in banking and finance, however they are mainly adopted by banking and finance firms themselves, not by groups of professional individuals and certainly not across the sector. ${ }^{151}$ They have not been effective. ${ }^{152}$ In the evidence to the Inquiry, there was virtual unanimity that there should be a 'unified professional body, which reflected a higher set of standards and expectations for individual behavior than those required by the regulator'. ${ }^{153}$

In Australia there is a Code of Banking Practice, but it is adopted and promoted by banking entities and through their representative industry body, the Australian Bankers Association. ${ }^{154}$ It is not a professionals' code applying to individuals. It is on the principles in such a code that the training for ethical and other competencies rest in established professions. It is code principles and derivative rules and guidance that are the point of departure for a professional association's investigative and disciplinary activities - the regulatory work that is the sharp end of any professional association's regulative bargain. In Australia as in Britain, there are many codes at entity level; in sub-groups across the financial sector, aspiring professional groups such as the Financial Planning Association

149 See Brent Fisse and John Braithwaite, 'The Allocation of Responsibility for Corporate Crime: Individualism, Collectivism and Accountability’ (1988) 11 Sydney Law Review 468, 469.

150 See Rogers, Kingsford Smith and Chellew, above n 21; Breakey and Sampford, above n 26.

151 Changing Banking for Good vol II, above n 4, 298.

152 There are many reasons suggested for this, but the leading one mentioned in the report was deficiencies in training due to courses in substantive technical expertise pushing out training for ethical and other principled decision-making: ibid 299.

153 Ibid 307.

154 Australian Bankers’ Association, Code of Banking Practice and Code Compliance Monitoring Committee Mandate (at 2013) <http://www.bankers.asn.au/Industry-Standards/ABAs-Code-of-BankingPractice/Code-of-Banking-Practice $>$. There are many other codes of conduct and ethics in the financial sector in Australia, and these often apply to personal members. However, because there are so many, their jurisdiction is fragmented and, except for the Australian Securities Exchange and the Financial Planning Association of Australia, none have a developed investigation and enforcement capacity. Tellingly, none has a sufficient membership to have the monopoly reach of a profession, or have a position strong enough to assert enough coverage to make a 'regulative bargain' for professional governance credible. 
have also adopted them to govern individual members. ${ }^{155}$ A frank overall assessment of Australian arrangements is very like the position in Britain: in banking, this aspect of professional identity and supporting professional association is weak. It is noticeably weak in relation to enforcement, as we discuss in Part VI below.

Drawing conclusions from what we have laid out in this Part, in the professional rules, certainly for lawyers, this duty to the professional institutions (eg, the administration of justice) and the public interest is made paramount, trumping any other duty where there is a conflict with it. It should be noted again that some critics say that the two elements of this paramount duty are in conflict. The first, the commitment to the institution, is alleged to exert a more conservative presence over the second, ${ }^{156}$ while the second might underplay the value of institutional stability in the first. Notwithstanding, this professional duty is compulsory and directory, and the hierarchy of duties is fixed: first to the public interest, second to other fundamental duties: the client, professional peers and the profession's own reputation. It is a constitutive obligation ${ }^{157}$ intended as the foundation of a collectively created good. These duties may be expressed without exception or permitting weighing or postponement. Like the medical oath that we have already mentioned, a traditional professional oath is a vow to discharge the duties 'even under threat': it is 'unconditional ... [and] generally binding despite changes in circumstances or the conditions under which they are sworn'. ${ }^{158}$ Sometimes a connected Code of Conduct will provide exceptions to an oath or allow prioritisation, judgment and discretion, ${ }^{159}$ which can be settled in individual cases to avoid offending, and to promote, the spirit behind oath obligations. ${ }^{160}$

By contrast, the different and more lenient quality of the bankers' oaths all take a 'stakeholder' approach to ethical priority and the competing interests of

155 The Financial Planning Association of Australia has adopted a code of ethics, established supervision and disciplinary arrangements, and abolished commissions as too conflicted a form of remuneration to coexist with the loyalty to clients required of a profession. It is too early to say whether these changes made over the last decade have resulted in the recognition of financial planners as a profession. See, eg, Deen Sanders, Professional Enlightenment of Financial Planning in Australia (PhD Thesis, Central Queensland University, 2010), which argues that the financial planning industry may not yet be ready to be considered a profession.

156 See Christine Parker and Adrian Evans, Inside Lawyers' Ethics (Cambridge University Press, $2^{\text {nd }}$ ed, 2014) 38.

157 As opposed to a negative prohibition, as is the case with much statutory regulation.

158 Boatright, above n 2, 145 (emphasis removed).

159 The authors are grateful to Dr Hugh Breakey for making these points and those in the two succeeding footnotes: Memo from Hugh Breakey to Dimity Kingsford Smith, Thomas Clarke and Justine Rogers, 22 August 2016. See also Patricia Greenspan, 'Making Room for Options: Moral Reasons, Imperfect Duties, and Choice' (2010) 27 Social Philosophy and Policy 181; Violetta Igneski, 'Perfect and Imperfect Duties to Aid' (2006) 32 Social Theory and Practice 439; Daniel Statman, 'Who Needs Imperfect Duties?' (1996) 33 American Philosophical Quarterly 211.

160 These exceptions and discretions help oaths and codes to keep their purposes clear, transparent and detached from the needs of those subject to them, and arrive at counter-intuitive outcomes when applied to unusual cases. See also Julia Black, Rules and Regulators (Oxford University Press, 1997) ch 6, which argues for multiple levels and forms of rule-making, including principles, rules and approaches to mitigate creative compliance, to preserve both purpose and certainty. 
those who might be served by bankers. ${ }^{161}$ A stakeholder approach permits the weighing and balancing of interests, potentially the elevation of one or more, and the discounting or complete disregard of others. ${ }^{162}$ Stakeholder approaches are familiar as the foundation for corporate social responsibility or 'social licence to operate' arguments for ethical corporate engagement with society and are clearly distinct from professionalism: they usually operate at the entity, not individual, level. Stakeholder approaches are valuable in widening the range of groups, harms and interests considered and providing flexibility. Indeed, the stakeholder approach and related business ethics models are being used in professional education because of these valuable qualities - even if there remains a problem with how to weigh and prioritise these. This is just one example of overlap or convergence between some status professions and banking and finance. There is something of a 'two-way traffic' in professions learning from other occupations as well, as they adapt to changing practice conditions and find new ways of enacting their values and standards. ${ }^{163}$

However, the stakeholder model's scope for recognising illicit or peripheral interests may distract from relevant or substantial ones. For example, a stakeholder approach would potentially allow an oath-taker to justify preferring the interests of a 'bully client' to the public interest or preferring their own bank employer to a client. ${ }^{164} \mathrm{~A}$ public-regarding professional duty makes it more difficult to justify 'internal decisions, unrelated to the objective needs of the wider world' 165 or 'decisions and behaviour that advance [a bank's] own narrow ambitions but harm the enterprise and the societies it serves' ${ }^{166} \mathrm{~A}$ professional who can 'serve all interests in good faith', as the Australian oath permits, may still put client interests before public ones. In the bankers' oaths, the only limits on this weighing approach seem to be that the oath-taker must not mislead or deceive any of those whose interests are at stake. ${ }^{167}$ This is not an emblem of professionalism; it is a common-place legal requirement of commerce. Moreover, in the context where total commitment of individual bankers to the banking entity

161 See, eg, The Banking and Finance Oath, above n 133: 'I will serve all interests in good faith'.

162 Stakeholder approaches to oaths employ a consequentialist or utilitarian ethic, rather than the deontological ethic. The latter adopts universal norms which are perfect duties (that is, which always apply); though as we have observed, there may be exceptions on a case-by-case basis to avoid counterintuitive outcomes.

163 See Parker and Evans, above n 161, 16-21 and their three-step model of ethical decision-making and behaviour that integrates both stakeholder and code approaches. Lawyers are also beginning to use the knowledge of business ethics educators and regulators on ethical decision-making and biases. They are teaching how ethical decision-making and behaviour occurs and how to address such decisions with others. This is a valuable way to internalise confidence to raise ethical matters, rather than simply teaching and relying on knowledge of the rules.

164 For example, the Banking and Finance Oath does not restrict the oath-taker from prioritising their employer's or shareholders' interests ahead of the public interest: see The Banking and Finance Oath, above $n$ 133, [2]. In the case of a traditional profession, the public interest is first, the legitimate client interest second and the employer interest thereafter.

165 Llewellyn, Steare and Trevellick, above n 97, 8.

166 Ibid 14, quoting the Harvard Master of Business Administration oath.

167 The guidance to the promise 'I will serve all interests in good faith' permits the swearer to weigh and prioritise interests, and in so doing, to put the employer bank first: The Banking and Finance Oath, above n 133. 
itself has overwhelmed public interests, one very telling distinction between professional obligations and stakeholder ethics is that the latter are generally voluntary and instrumental, while professional ethics generally are not. Such differences between the stakeholder approach and professional logic are important in considering whether banking has the potential to professionalise.

\section{DUTY TO THE CLIENT}

Adam Smith's observation some 240 years ago that we 'trust our health to the physician; our fortune and sometimes our life and reputation to the lawyer and attorney' remains grounded in their fidelity and judgment. ${ }^{168}$ Professional knowledge is, or should be, ${ }^{169}$ developed and delivered primarily for the benefit of clients, in support of social institutions that are vitally important, such as public health, the administration of justice and the core concern of engineering, the physical safety of the public.

\section{A Professionalism and Duties of Loyalty and Confidence}

In many relationships in banking (recollecting that we use this term to include finance) but not all, as discussed below, the law protects the relationship of banker and customer by the application of the fiduciary duty. The importance of this to the question of professionalism is that in some areas of banking, there are already requirements which serve to cement a higher standard of duty to the customer or client than those of ordinary commerce. There is clear authority that trustees, ${ }^{170}$ investment managers, ${ }^{171}$ stockbrokers ${ }^{172}$ and financial advisers ${ }^{173}$ may owe fiduciary duties. Whether corporate financial advisers are fiduciaries is even more context dependent and reliant on the terms of the advice mandate. ${ }^{174}$ It is also accepted that the debtor and creditor relation common to most banking is not fiduciary, ${ }^{175}$ and likewise over-the-counter ('OTC', or principal-to-principal) transactions with clients and banks' proprietary trading activities. These observations lead to a further one: that some parts of banking may be better candidates for professionalism than others, at least in principle. As we elaborate

168 Adam Smith, Wealth of Nations (Oxford University Press, first published 1776, 1998 ed) 82.

169 The professions have, however, also been criticised as being self-serving by controlling a monopoly on their market and status: see, eg, Rogers, Kingsford Smith and Chellew, above n 21; Magali Sarfatti Larson, The Rise of Professionalism: Monopolies of Competence and Sheltered Markets (Transaction Publishers, 2013).

170 Hospital Products Ltd v United States Surgical Corp (1984) 156 CLR 41, 68 (Gibbs CJ).

171 Investment managers are often trustees, and when they are not will often be agents and fiduciaries: see SPL Private Finance (PF1) IC Ltd v Arch Financial Products LLP [2014] EWHC 4268 (Comm).

172 Daly v Sydney Stock Exchange Ltd (1986) 160 CLR 371, 377 (Gibbs CJ), 385 (Brennan J).

173 ABN AMRO Bank NV v Bathurst Regional Council (2014) 224 FCR 1, [1063]-[1072] (The Court); Wingecarribee Shire Council v Lehman Brothers Australia Ltd (in liq) (2012) 7 BFRA 1, [733] (Rares J).

174 ASIC v Citigroup Global Markets Australia Pty Ltd (No 4) (2007) 160 FCR 35, [266] (Jacobson J); Andrew Tuch, 'Investment Banks as Fiduciaries: Implications for Conflicts of Interest' (2005) 29 Melbourne University Law Review 478. 
below, these areas tend to be where advising is central to the customer or client relationship. This is in contrast to the trading of financial instruments or the making of credit contracts, which are the financial functions of large parts of the banking sector, and acknowledged as its riskiest and most profitable ones.

Like the oaths and affirmations we have discussed above, fiduciary duties are mandatory. They can only be relaxed with the fully informed consent of the beneficiary of the duty. ${ }^{176}$ Because of failures in obtaining this consent in consumer financial markets, there are now statutory limits in retail advising on when and whether a beneficiary of a fiduciary duty can agree or contract to waive their protection. ${ }^{177}$ While fiduciaries have many duties, only some are peculiar to the fiduciary relationship. ${ }^{178}$ Those that are particular to the fiduciary are often described as those that 'comprise that notion of loyalty'. ${ }^{179}$ The first duty central to fiduciary loyalty 'prohibits a fiduciary from acting in a situation in which there is a conflict between the duty he owes to his principal and his personal interest'. ${ }^{180}$ The second 'prohibits a fiduciary from receiving any unauthorised profit as a result of his fiduciary position'. These conflict duties are the 'irreducible core of the fiduciary obligation'. ${ }^{181}$

Some argue that, as well as the two arms of the loyalty duty, there is another duty in equity which requires a fiduciary to act 'in the best interests' of the beneficiary client. ${ }^{182}$ While this duty has a relatively clear provenance and content in trust law, it is far less settled in its application to other advisory or fiduciary contexts in banking. ${ }^{183}$ Some reject its application here entirely. ${ }^{184}$ This uncertainty has recently been addressed by the adoption of a statutory 'best interests' duty applying to financial advising. ${ }^{185}$

176 Simone Degeling and Jessica Hudson, 'Fiduciary Obligations, Financial Advisers and FOFA’ (2014) 32 Company and Securities Law Journal 527, 534-7; Wingecarribee Shire Council v Lehman Brothers Australia Ltd (in liq) (2012) 7 BFRA 1, [746] (Rares J).

177 Corporations Act 2001 (Cth) s 960A.

178 For example, fiduciaries have a duty of care to their beneficiaries but this is not a duty of a fiduciary quality: 'not every breach of duty by a fiduciary is a breach of fiduciary duty': Bristol and West Building Society $v$ Mothew [1998] Ch 1, 16 (Millett LJ).

179 Above n 176

180 Ibid 39. This duty now has a statutory analogue in retail financial advising prohibiting commissions and other forms of conflicted financial remuneration; Corporations Act 2001 (Cth) pt 7.7A, div 4, sub-divs A-C.

181 Ernest J Weinrib, ‘The Fiduciary Obligation’ (1975) 25 University of Toronto Law Journal 1, 16.

182 Geraint W Thomas, 'The Duty of Trustees to Act in the "Best Interests” of Their Beneficiaries' (2008) 2 Journal of Equity 177, 178-9.

183 Cowan v Scargill [1984] 2 All ER 750; Sir Robert Megarry, 'Investing Pension Funds: The Mineworkers Case' in T G Youdan (ed), Equity, Fiduciaries and Trusts (Law Book, 1989) 149, 152-3. The discussion about the nature and extent of fiduciary duties continues: see Sarah Worthington, 'Fiduciaries: Following Finn’ in Tim Bonyhady (ed), Finn's Law: An Australian Justice (Federation Press, 2016) 33; Paul Finn, 'Fiduciary Reflections’ (2014) 88 Australian Law Journal 127, 127-8; Paul Finn, Fiduciary Obligations: $40^{\text {th }}$ Anniversary Republication with Additional Essays (Federation Press, 2016); Paul Finn, 'Contract and the Fiduciary Principle' (1989) 12 University of New South Wales Law Journal 76.

184 Breen $v$ Williams (1996) 186 CLR 71, 113 [40] (Gaudron and McHugh JJ).

185 Corporations Act 2001 (Cth) pt 7.7A, div 2; Australian Securities and Investments Commission, Regulatory Guide No 175: Licensing: Financial Product Advisers - Conduct and Disclosure (at 3 October 2013). 
While duties of confidence are often referred to in the same breath as fiduciary duties, they are not exclusive to the fiduciary relationship, though overlapping. Conaglen argues that 'the prevailing view is that the foundation of the doctrine of confidence no longer rests in the protection of property', ${ }^{186}$ but is better considered as derived from 'the obligation of conscience arising from the circumstances in or through which the information was communicated or obtained'. ${ }^{187}$ Whatever its foundation or nature, the practical reality in most contexts is that the banker has received information for the purposes of the relationship and is bound to keep it confidential. This is also generally considered a feature of professional relationships. In banking (in our extended sense) it is clear that some relationships are fiduciary and virtually all attract, or are treated as attracting, a duty of confidence; our central question is whether these relationships also could be professional. ${ }^{188}$

\section{B Professionalism and Client Vulnerability}

The professional responsibility to care for clients is often explained, in economic analyses, as arising from an asymmetry of knowledge between the two. But even where the client is knowledgeable, professional relations are profoundly interpersonal, as Sulmasy, Boatright and Breakey each point out. ${ }^{189}$ Speaking of the medical profession, Pellegrino puts it in more expressly ethical terms: that it is the radical vulnerability of the patient in their illness with diminished agency ${ }^{190}$ and 'no recourse but trust' 191 that morally demands a reciprocal professional duty which vindicates the patient's trust. '[It] is a special moral claim with a special moral commitment'. ${ }^{192}$ Signified and enacted by the professional oath, the professional makes 'a commitment to be a certain kind of person for other persons'. ${ }^{193}$ The professional 'who swears an oath not only puts his or her personhood on the line, he or she does so for the sake of a connection' to those for whom the oath is taken: in the case of a professional, this includes (but as we have discussed is not limited to) their clients. ${ }^{194}$ The law recognises this vulnerability and the client's forced dependence on trust in advisory relationships such as advisor, broker, trustee, and investment manager. It enforces the moral commitment of the professional to serve the vulnerability of the client through the fiduciary duties of loyalty and the duty of confidence.

186 Matthew Conaglen, Fiduciary Loyalty: Protecting the Due Performance of Non-Fiduciary Duties (Hart Publishing, 2010) 242.

187 Moorgate Tobacco v Phillip Morris [No 2] (1984) 156 CLR 414, 438 (Deane J), quoted in Breen v Williams (1996) 186 CLR 71, 81 (Brennan CJ).

188 Not all professional relationships, however, are fiduciary: see, eg, Breen v Williams (1996) 186 CLR 71 regarding the relationship between the doctor and patient.

189 Sulmasy, above n 134, 332-4; Boatright, above n 2; Breakey, above n 28.

190 Edmund D Pellegrino, 'Toward a Reconstruction of Medical Morality: The Primacy of the Act of Profession and the Fact of Illness' (1979) 4 The Journal of Medicine and Philosophy 32.

191 Sulmasy, above n 134, 341.

192 Ibid.

193 Ibid 333.

194 Ibid 334. 
The vulnerability of ordinary bank and financial services customers, particularly in relation to investing decisions, is well documented, ${ }^{195}$ but perhaps under-recognised in the professions' debates. As with medical, legal, or engineering expertise, the financial knowledge and capability of most individuals is low. ${ }^{196}$ Meanwhile, over the last generation, significant financial responsibility has been devolved to individuals. ${ }^{197}$ Financial decision-making has become both more complex and more necessary with the increasing 'financialisation' of everyday life. ${ }^{198}$ The autonomy of an individual is diminished if they cannot access financial resources and their life chances and welfare may be reduced. In some tragic cases, significant financial loss or financial exclusion literally becomes a matter of life and death. Individuals are vulnerable to the quality of interaction with the financial system and, as in the medical context, the majority have 'no recourse but trust'. ${ }^{199}$

\section{Shared Expertise and Training and Competence}

One of the ways in which the quality and advancement of the expert knowledge of a professional is assured and the fiduciary duty fostered is through systematic training and qualification for professional formation and continuing education. ${ }^{200}$ Many non-professional occupations and emerging professions also have systematic education requirements, some quite significant, though not usually as high as the professions. ${ }^{201}$

By contrast, training for work in banking is fragmented and there are no universally recognised core subjects and no universal standards or qualification. Likewise, there is no general requirement for continuing education. Though continuing training occurs on the variety and complexity of trends and products in finance it is as variable and split up as the sector itself. ${ }^{202}$ In practice, bankers usually do have a university degree and allied practical training, whether or not this is required. However, there is no agreed qualification that makes those in banking and finance into a 'banker', ${ }^{203}$ and some doubt whether this is even possible. ${ }^{204}$ Hall and Appleyard provide evidence that the most intense and formative training occurs with new recruits in banking, providing identity with the firm, ${ }^{205}$ rather than a wider professional group. The UK Parliamentary

195 See the discussion of the 'behaviouralist' and financial literacy aspects of this in Dimity Kingsford Smith and Olivia Dixon, 'The Consumer Interest and the Financial Markets' in Niamh Maloney, Eilís Ferran and Jennifer Payne (eds), The Oxford Handbook of Financial Regulation (Oxford University Press, 2015) 695.

196 Ibid.

197 Ibid.

198 Ibid.

199 Sulmasy, above n 134, 341.

200 Andrew Boon and Jennifer Levin, The Ethics and Conduct of Lawyers in England and Wales (Hart Publishing, 2008) 77.

201 See discussion of new education requirements for Financial Planning Association members below in text accompanying nn 208-209.

202 Hall and Appleyard, above $\mathrm{n} 33$.

203 Changing Banking for Good vol II, above n 4, 295.

204 Ibid 296-7.

205 Hall and Appleyard, above n 33. 
Banking Inquiry concluded: “Banking” involves a wide range of activities and lacks a large common core of learning which is a feature of most professions' ${ }^{206}$ The Inquiry deplored the fact that many banks have senior executives and directors with little or no qualification for the work they do. ${ }^{207}$

Although banking might lack a 'common core of learning', there are some areas of deliberate and self-conscious improvement where standards and processes are being developed, and most importantly the politics of change are practiced, which might provide a wider template for the sector. In its attempts over the last 15 years to professionalise, the Financial Planning Association of Australia ('FPA') recognised the extreme modesty of current education and training requirements of its members and has taken steps to address this. The FPA promotes a Certified Financial Planner ('CFP') membership. Almost half of its 12000 members now hold this certification, which represents a significant proportion of the financial advice sector. ${ }^{208}$ The CFP requirements are modelled on those required for other professions. A CFP must hold a university degree, have at least three years of relevant industry experience and complete five CFPspecific training courses, each of a few months in duration. ${ }^{209}$ By increasing requirements beyond low government regulatory requirements ${ }^{210}$ towards those of the established professions, financial advisers have developed common structures for competence on entry, maintaining currency of expertise and strengthening identity.

Overall, this picture of banking training and competence shows pathways towards qualification at variable levels of development. Ideally these paths would assure high quality, ethical knowledge and skills, comparable to established professions with more specialised knowledge and training at earlier stages, and greater harmonisation. In the meantime, to the UK Parliamentary Banking Inquiry, the absences in commonality of education and training were strong evidence supporting their conclusion that banking is not professionalised. The Inquiry also concluded that from the expertise and education perspective, banking is not ready to be a profession. ${ }^{211}$

\section{Professionalism and the Giving of Advice}

As well as their expertise, the fiduciary quality of trust we discussed above is also seen in the expectation that the professional will use their judgment to advise on the client's particular circumstances. To do this, the client must be able to confide in the professional and reveal confidential information as the parallel and overlapping duty of confidence permits. So armed, the professional is expected to

206 Changing Banking for Good vol II, above n 4, 306.

207 Ibid 308-9.

208 Financial Planning Association of Australia, Membership <http://fpa.com.au/membership/>.

209 Financial Planning Association of Australia, About the CFP Program <http://fpa.asn.au/cfp/cfpcertification-program/>.

210 See Australian Securities and Investments Commission, Regulatory Guide No 146: Licensing: Training of Financial Product Advisers (at July 2012). This low standard is likely to be raised by the recent passing of the Corporations Amendment (Professional Standards of Financial Advisers) Act 2017 (Cth).

211 Changing Banking for Good vol II, above n 4, 308. 
employ their expertise and judgment to respond to the particular needs of the client and provide appropriate tailored or bespoke advice using discretionary judgement, ${ }^{212}$ not general advice. In banking, much of the sector does not give advice, or does so only incidentally and not in a fiduciary capacity. Instead, banking institutions often and increasingly buy and sell financial contracts between themselves and to their clients as counterparties. They do so while providing objective information about price and execution, not giving personal advice. Instead, much banking activity involves commercial trading and contracting. ${ }^{213}$

In a wider discussion of bank culture, the President and CEO of the New York Federal Reserve noted the further shift towards transactional, arm's length relationships and their impact on ethics:

Another important element affecting culture has been the shift in the prevailing business model away from traditional commercial and investment banking activities to trading; that is, from client-oriented to transaction-oriented activities. Clients became counterparties - the other side of a trade - rather than partners in a long-term business relationship. In general, interactions became more depersonalized, making it easier to rationalize away bad behavior, and more difficult to identify who would be harmed by any unethical actions. ${ }^{214}$

These insights of financial insiders, that banks transact with clients as much as they provide advisory services for them, reveal another potential lack of fitness of the financial sector for professionalism. Investment banks, or investment banking divisions within conglomerate full-service banks, for instance, earn much of their revenue from proprietary trading. Proprietary trading occurs when the bank uses its own funds to trade against the market in financial products for its own account (ideally profitably), not that of its clients. While under the post-GFC structural reforms there have been regulatory curbs on proprietary trading by commercial banks (described in Part II), ${ }^{215}$ proprietary trading continues to grow as a source of revenue for investment banks

By contrast with proprietary trading, where the counterparty is not a customer, in the OTC markets the bank may enter into a contract directly with the client as counterparty. That is, the bank may seek to profit on the contract with the client by taking an opposing position. In doing so, the bank may depart from the standardised terms governing OTC transactions and negotiate special or bespoke terms as to lot size or settlement, against its 'client' counterparty. A bank having a client as counterparty on a contract with a view to speculative profit is very common in derivatives trading and extends to other financial products.

There are, of course, banking activities that are closer to the professional advisory relationship, for example share broking transactions (most banks have a broking arm). Here, the bank may provide advice on share selection and then execute the buy or sell order on the customer's behalf. It earns a fee or

\footnotetext{
212 Australian Securities Commission v Cassimatis [No 8] (2016) 336 ALR 209, 326 [609] (Edelman J).

213 Ibid 295.

214 Dudley, above $n 88$.

215 See, eg, Dodd-Frank Act, 12 USC §§ 5301-5641 (2012), referred to as the Volcker Rule.
} 
commission from providing the advice and acting as an agent for the client to access the exchange, not a profit on the transaction. In this kind of service provision, like the other advisory services we discuss below, the relationship of broker to customer is clearly both advisory and fiduciary. Traditionally it has also been personal, though this is changing with self-directed non-advisory online investing. Between the contrasts of what we have called the transactional approach and advisory services lies myriad other interactions between bank and customer.

An important example to show how a direct, seemingly personal client relationship can be neither fiduciary, nor even truly advisory, is the extension of credit to customers. The extension of credit may be through a credit card or car loan, home loan, business loan or, as was previously offered by merchant banks, a trade credit facility. These days, many of these loans do not require even meeting with a banker and can be obtained over the internet without advice. Even when loans are provided through personal meetings, most are so standardised that whether they are offered depends exclusively on the financial capacity to repay and/or availability of security. ${ }^{216}$ Financial information may be offered by the banker, but advice requiring expert knowledge and judgment in relation to a loan is rare. This is also true of simple financial products offered by banks, such as savings and term deposits. ${ }^{217}$ The role of the bank teller or loan officer is to describe the terms of the products and identify for the customer the loan packages that the bank would be prepared to offer them. While there is a bank and customer relationship here, its personal quality is attenuated by the standardised nature of the loan contracts and their manner of distribution, especially online. The relationship is contractual and not fiduciary, though bankers do have a duty of confidence in relation to the customer's financial information. The picture is similar even in relation to high net worth personal customers and small to medium businesses.

Closer to the advice end of the spectrum, investment bankers provide advice to large corporations and governments on raising capital and on mergers, acquisitions, restructuring and privatisation transactions. The bank will then usually direct the implementation of the transactions they have recommended, taking a fee for advice, a success fee or a mixture of both. Banks also have investment management arms. Under an investment mandate, they generally exercise discretionary powers to invest on behalf of a client with large pools of assets, often for retirement income. Banks also usually have retail financial planning or advising businesses, offering advice for the practical purpose of building and protecting personal and household wealth. Unless excluded by

216 Changing Banking for Good vol II, above n 4, 308 refers to this process of assessment as 'credit scoring'. See generally Evzen Kocenda and Martin Vojtek 'Default Predictors and Credit Scoring Models for Retail Banking' (Working Paper No 2862, CESifo, December 2009).

217 See Corporations Act 2001 (Cth) ('CA'); Corporations Regulations 2001 (Cth) ('CR'), which allow basic banking products such as savings and term deposits to be sold without a wide range of protections, including disclosure documents ( $C A$ ss 941C, 946AA; $C R$ regs 7.7.09A, 7.9.07FA), the requirement to put the client first (CA ss 961(1), 961J(2)), and the full obligation to act in the client's best interests ( $C A$ ss 961(1), 961B(3)-(5); $C R$ reg 7.7A.05). This is so if only financial information is given or only general advice is given or if personal advice is given for an amount under $\$ 15,000$. 
contract, the advisory relationship in all of corporate and retail financial advising, stockbroking and investment management is fiduciary, though as we have already observed, because other elements such as a public purpose or common education are missing, not necessarily professional.

\section{DUTY TO PEERS AND PROFESSION}

Reverting once again to the earlier articles in this Issue, the reader will have observed that an important duty of a professional is to his or her peers, and wider professional group. Often, this norm finds expression in codes of ethics as a requirement to act with respect, civility and without misleading peer professionals with whom one is dealing. More broadly, professionals must act in a way that does not bring the profession into disrepute. It is hoped that these duties are fostered by peer mentoring as well as the mechanisms outlined above, common knowledge and training, and the rituals of shared professional purpose and identity: a self-awareness that finds further solidarity in membership of a professional association, as we soon consider.

It is worth also pointing out that the state's role in offering some degree of protection from ultra-competitive commercial concerns is seen as a valid means of incentivising and supporting professional independence and responsibility. Professional peer civility allows professionals to get on with being professional, that is, with collegiality and altruism, things they cannot do if concerned with acquiring and maintaining authority and status. ${ }^{218}$

Peer relations in banking, by contrast, are characterised by intense competition, ${ }^{219}$ and not shared purpose, peer respect or jealous guarding of common reputation. However, and encouragingly, there are some efforts among this sector to inculcate collegiality and more collegiate relationships. One of the strengths of the Australian Banking and Finance Oath organisation, reviewed above, is the community of like-minded people it connects who prioritise ethical behaviour. The organisation provides opportunities for learning, discussion, scenario analysis, and seeking the support of other signatories. ${ }^{220}$ Possibly replicating the professional mentorship model, it concentrates on recruiting senior and experienced bankers and on hosting events and discussions to educate its oath-takers. This seems to us to be a start in supplying the platform for the wider norms of professional ethos (public purpose and clients) to flourish, as well as developing the ethos and routines for professional association with peers.

218 Michael Burrage and Rolf Torstendahl (eds), Professions in Theory and History (Sage Publications, 1990).

219 Financial Crisis Inquiry Report, above n 5, 28-52, 210-11, which discusses competition as a factor in the crisis; Murray Report, above n 16. See especially the discussion of Recommendation 30 in the Murray Report, which suggests competition between banks at an institutional level is less intense in Australia: at 254-256. Our discussion of the inciting effects of remuneration above, also feed into the conclusion that competition is at both an institutional and individual level.

220 The Banking and Finance Oath, Programs (2015) <http://www.thebfo.org/Programs>. 


\section{PROFESSIONAL SELF-GOVERNANCE IN BANKING AND FINANCE}

Professionalising requires a professional association, which as indicated in earlier articles, enjoys more or less a monopoly of control over the myriad activities that are enablers and preservers of professions and their social promise. It is through professional associations that the political project of the regulative bargain with the state is implicitly concluded. Under this 'bargain', professional self-governance is exchanged for the guarantee of self-denying service by professionals in the public interest and expert advice to clients. In the case of banking and finance, the possibilities of professional self-governance are seriously curtailed by: firstly, the low levels of association membership; secondly, by the century-long presence of state legislated regulatory regimes reflecting the central importance of banking entities to modern economies; and thirdly, the further regulation in banking and finance since the GFC and LIBOR scandals, motivated by public and political mistrust and the austerity endured by financial consumers and taxpayers alike because of financial failures (either rescued or realised). The latter was discussed in Part II above. In this Part, we examine the practical and political possibilities for a contribution to the regulation of banking and finance through professional self-governance, given the sector's desire for it.

It is not easy to imagine the circumstances, either practical or political, in which the state would agree to a regulative bargain to give up the compulsory powers of regulation and enforcement over the personnel of banks and financial institutions, let alone the entities themselves. It is arguable that a different sort of regulative bargain has already been struck with the sector: the exchange of limited liability and public subsidies enjoyed by banks (for example, central bank lending facilities and deposit guarantee schemes) for the regulation which is ubiquitous in the sector. The attempts by the British banking industry to persuade the UK Parliamentary Banking Inquiry that the industry could feasibly and credibly self-regulate as a profession were mostly dismissed as an indefensible power-grab. Indeed, from the analysis we have already given, the reader will likely have concluded that institutionalising the professionalism of individual conduct in the sector has immense obstacles to overcome. However, we advocate greater ethical self-consciousness in banking as suggested by the adoption of oaths and codes, ethical and technical education, and the identification and adoption of a public interest that banking supports - in short, that professionalisation still has contributions to make and that it should make, and a professional association is central.

To be successful in self-governance, the professional association needs to have the vast majority, if not virtually all the individuals practicing, as members. Otherwise, its standard-setting, training, collegiality-building and representation have insufficient grip to establish legitimacy and authority - both internally to the profession itself and externally. Unfortunately, professional association 
amongst bankers is weak.221 In Australia the Australian Bankers Association is an industry representative body comprised of banking entities and does not have individual membership. ${ }^{222}$ Otherwise there is the Australian Investment Bankers Association, ${ }^{223}$ which limits its membership to corporate advisers. There are many other sub-sectoral associations such as the FPA discussed above, which reflect sector fragmentation and, with some exceptions, professional ethos within them is not well developed. In Britain, while there are professional banking associations, their membership has declined to less than 10 per cent of what it was 30 years ago. ${ }^{224}$ Of the 450000 employees in banking, only a very small number (about 30000 ) belong to these professional associations. ${ }^{225}$ Accordingly, the sector lacks professional membership of an association that could plausibly be a party to a regulative bargain delivering self-governance.

To make self-governance credible, the professional association needs not only to be able to set standards, but to have meaningful disciplinary power over its members, especially the power of expulsion. Enforcement of professional regulation has always been a weakness even in established professions. ${ }^{226}$ To start with, there is an inherent conflict in a professional association managing both representative and regulatory responsibilities. If they remain domestic tribunals and power over members derives from a contract of membership, associations have limitations on their investigation and disciplinary powers. They have no powers of compulsion: surrendering of information or documents and attendance at hearings depends almost entirely on cooperation by the person under disciplinary consideration. ${ }^{227}$ Further, where evidence depends on third parties and not members of the profession - for example a professional's corporate employer like a bank - there is no power at all to require evidence or other cooperation, since they are not contractually bound. Likewise, the enforcement of sanctions is limited: a domestic tribunal resting solely on contractual powers has no practical ability to collect fines or to compel supervised practice, further

221 Changing Banking for Good vol II, above n 4, 296.

222 See Australian Bankers’ Association, Members (December 2016) <http://www.bankers.asn.au/AboutUs/Members>.

223 Australian Investment Banking Association, About <http://aiba.org.au/about/>.

224 The Chartered Banker Institute (now IFS School of Finance) and the Chartered Institute of Bankers in Scotland: in the 30-year period between the 1980s and 2010, the membership of the former had dropped from 150000 to 22000 and it was no longer expected that someone aspiring to senior positions in banking would be a member or have qualifications offered by the Chartered Banker Institute. See Changing Banking for Good vol II, above n 4, 295. It was also revealed in evidence by the Royal Bank of Scotland and HBOS that the Chairmen and Chief Executives of these banks did not have a banking qualification between them: at 296.

225 Ibid 296.

226 See, eg, Dimity Kingsford Smith, Submission to Financial System Inquiry Committee, Financial Systems Inquiry, 2014, 19-20; Murray Report, above n 16, 204. See generally Justin O’Brien et al, 'Professional Standards and the Social Licence to Operate: A Panacea for Finance or an Exercise in Symbolism?' (2015) 9 Law and Financial Markets Review 283, 285-7 for critique of the potential for professionalising the banking sector and the hesitancy of banking associations such as the British Banking Association to enforce standards on members.

227 JRS Forbes, Justice in Tribunals (Federation Press, $4^{\text {th }}$ ed, 2010). However, professional membership rules typically state that failure to cooperate itself leads to expulsion. The member's failure to assist is taken as a rejection of any desire for reintegration and return to good standing as a professional. 
education and so on. Admonition alone is likely too lenient and expulsion will often be out of proportion with the breach.

For a variety of reasons which are canvassed in previous articles, even established professions no longer enjoy complete self-governance. Since the 1990s, they have each had to adopt models of either formal co-regulation with the state or else have become government regulated, with the professional association relegated to an informal, secondary role. ${ }^{228}$ In these professions, coregulation extends to investigation and disciplinary activity, with enforcement undertaken by statutory agencies that exist in parallel with professional associations. In some instances, the statutory investigation and enforcement powers are delegated to and exercised by the professional bodies themselves with statutory accountability. ${ }^{229}$ In banking and finance, any arrangements to invigorate associational enforcement would be further complicated by overlap with long-standing statutory regulation of individual conduct by banking and financial services regulators. Although public enforcement against individuals has its difficulties, and the focus is on entities, there is great reluctance by financial regulators to give up powers to a professional body because this complexity may add to existing difficulties. ${ }^{230}$ In summary, any professional association in banking must overcome these obstacles before it could provide a focus for professional recognition and regulatory autonomy.

\section{CONCLUSION: THE LIMITS OF PROFESSIONALISM}

We draw our argument to a close by identifying from our discussion the limits of professionalism and how banking might adjust to a professional framework in future. Put another way, we use our conclusions to consider what banking might look like if it were to take professionalism seriously, as well as rhetorically. We hope this concluding analysis may also assist other occupational groups with aspirations to professionalise.

\section{A Entity Separation, the Real Economy and the Public Interest}

Demands for more professionalism, including this analysis, are generally hopeful about changing the motivations of individuals, so they make better decisions and conduct improves. To achieve this and for the reasons we have given - risky business, the pursuit of profit, imprudent incentives and the diverse mix of fiduciary and non-fiduciary functions in banking with various prospects

228 For example, the law profession is now regulated under a co-regulatory model with, in NSW, the Law Society of NSW having a formal co-regulatory role in conjunction with the statutory regulator, the Legal Services Commissioner, under the Legal Profession Uniform Law 2014 (NSW). In the area of health, 14 medical and allied health professions, including doctors, nurses and midwives, radiologists, occupational therapists, chiropractors, osteopaths, psychologists and Chinese medicine practitioners, are now all regulated in Australia under a National scheme with the various, related professional associations having no formal co-regulatory role: see, eg, Health Practitioner Regulation National Law 2009 (NSW).

230 Changing Banking for Good vol II, above n 4, 305. 
for professionalising - we conclude it is very likely that greater professionalism will demand greater entity separation. To professionalise banking through serving the public interest and/or a socially important institution, as argued in our discussion of oaths, it seems inevitable that banks will need to renew their attention to the real and retail economies. Likewise, if banking is to serve better its fiduciary advisory clients and its customers seeking credit.

As the post-GFC investigations showed, risky proprietary trading (when it goes well) is largely for the profit of the entity. Along with the reasons of prudence and institutional resilience that the post-GFC reformers argued, we think that separation would make it easier to evolve a public interest ethos distinctive to the socially beneficial activities of traditional business, commercial and financial consumer banking, undiverted by proprietary trading. As the industry voices we quoted in Part II pointed out, simpler entities are easier to govern, and we argue that includes governance through professionalism. A comparatively singular focus would allow potential bankers to undergo professional formation and develop identity with a clear, public purpose, buttressed by shared ideals and practical ethical support as part of an (emerging) professional group. They could concentrate on products and services beneficial to clients and customers, and to the economy and society more widely. Governance of a simpler organisation, which clarifies and expects that executive authority will support individual ethical decision-making, would legitimate professionalism in a setting driven by profit and remuneration. We have pointed out the plausibility (and LIBOR showed the reality) of non-professional executives accepting (or through remuneration and other practices tacitly encouraging) unethical or unlawful conduct. Separation of wholesale and proprietary functions from real economy and customer-facing banking has been required by regulation for prudential reasons. Our first conclusion is that this could be leveraged to encourage fiduciaries and/or professionals (in the making) to operate more ethically in the wider public and client interest.

\section{B Firm Ethos, Professional Ethos and the Importance of Professional Association.}

Our second conclusion is that for banking to professionalise firms will need to resolve the tension between firm ethos and professional ethos. As the research demonstrates the firm is an alternative and even opposing site of identity, training, and, most powerful of all, remuneration tied to firm success. Firm allegiance has corroded individual membership of professional associations where that opportunity exists, and crowded out values other than those of the firm.

More particularly, banking will need to encourage individual membership of a professional association if banking is to advance towards a public commitment. Banking has shown an awareness of the need for a public commitment, as exhibited by the oaths we have reviewed, but how should such an oath be formulated? Could an oath and core duty be to advance 'the economic prosperity 
and welfare of the public'? ?231 On analogy with medicine, could bankers promise to 'advance the financial health of the economy and the personal, domestic and household financial wellbeing of the members of the public' ${ }^{232}$ or, mirroring the engineers' oath, to 'advance the financial safety, the economic prosperity and welfare of the public'? Alternatively, should banking 'provide security and prosperity for its customers, and to enable the flourishing of their communities in a manner that is responsible'? ${ }^{233}$ Finally, the Australian Bankers Association identifies a purpose of the type we are discussing. It describes its purpose as being 'to ensure the banking industry is recognised widely as an essential and responsible contributor to Australia's prosperity'. ${ }^{234}$ Reworded, this could become a statement of professional purpose: 'to serve banking and finance so it is an essential and responsible contributor to the prosperity of Australia and the members of the public'. However, none of these formulations will make professionalism possible if professional association is weakened by firm allegiance. It is practically impossible to develop a sector-wide or even sectional identity and sense of professional purpose where independent association is weak or non-existent. From that association independent of the banking firm flows greater possibility of common professional purpose, ethical and educational standards, professional mentoring and shared identity. The artifacts such as codes of conduct, and routines of professionalism including mentoring and advice about how to discharge professional obligations in hard cases, would also emanate from the professional association.

\section{Coexistence of Government Regulation and Professional Autonomy}

As other articles in this Issue make clear, even established professions now exist in a regulated environment. ${ }^{235}$ Indeed, it is accurate to say that established professions are particularly likely to be heavily regulated, given the vital public interest in their services. Were banking to professionalise it would not be exceptional in having to limit the traditional professional desire for regulative autonomy to co-exist with government regulation. So our third conclusion is that a banking professional association would need to lead its members to see the benefits of co-regulation with the government, given that in a post-GFC world the deregulation of banking is politically unlikely. What would this co-regulation look like, and what might be its limits?

As in traditional professions a professional banking association should be an important voice in regulatory reform, whether identifying gaps in need of new regulation, bringing old regulation up-to-date or in developing associated policy. Though working in a regulated environment, an association could bring forward many of the benefits of self-regulation: practical and expert knowledge; a

\footnotetext{
231 See also Reserve Bank of Australia Act 1959 (Cth) s 10(2)(c); Dutch Banking Association, above n 131.

232 Australian Treasury officers sometimes refer to financial advisers as providing a 'prescription' for individuals needing a strategy for a return to or for the maintenance of financial good health.

233 Llewellyn, Steare and Trevellick, above n 97, 8. However, the suggested oath (at 14) does not really capture this as the purpose of the promises that the British banker might swear to.

234 Australian Bankers’ Association, History <http://www.bankers.asn.au/About-Us/History>.

235 See Rogers, Kingsford Smith and Chellew, above n 21.
} 
perspective independent of banks themselves; and most relevantly, a perspective informed by the public interest.

Cotterrell observes that government regulation may be perceived as external and illegitimate. ${ }^{236}$ Applied to banking, it is not difficult to see how the prudential and protective purposes of regulation could be seen as lacking legitimacy with the regulated group's occupational and social norms: norms tied to risk, profitseeking and high remuneration. As professions have (or should have) a constitutive ethos of commitment to the public interest and client purposes, common ground with public regulatory objectives properly understood should be easier to find than might be the case between professional and firm values. One mode of co-regulation is associational leadership so members believe that it is right to give priority to others' interests and in the process improve or even exceed what is needed for compliance with 'outside' regulation. Such leadership to address professional and regulatory commonalities may help professionals be less inclined to 'creative-compliance' and other resistant conduct. ${ }^{237}$ Practical examples of this might be found in codes of conduct, where professional obligations are required to be discharged at a higher standard than analogous legislative ones. Likewise in training professionals in how to conduct ethical conversations with employer firms, and sometimes with clients, to justify and enact more public-regarding conduct. These are the sorts of difficult conversations the Australian Banking and Financial Oath organisation mentors for. These initiatives are all the more important when it is realised that in banking, as elsewhere, enforcement is in practice 'spread around thinly and weakly'. ${ }^{238}$ So regulators depend on the internalisation of program purposes by the regulated (and professionalised) for the practical realisation of regulatory objectives.

It is, however, reasonable to be sceptical about how much responsibility can be placed on individuals to act ethically when professionalism is undeveloped and when entity structure and incentivised high remuneration remain inimical, executive authority is not professionalised, and professional peer support is scarce. This involves finding a balance between pushing down liabilities to individuals ${ }^{239}$ and driving liabilities home to the entities that employ them. ${ }^{240}$ This issue identifies perhaps the most difficult arena for banking co-regulation, the enforcement context: this is where the established professions have co-regulated most thoroughly but banking may face greater obstacles. As is elaborated in this Issue, ${ }^{241}$ traditional professions have co-regulated by providing disciplinary

236 Roger Cotterrell, The Sociology of Law: An Introduction (Butterworths, $2^{\text {nd }}$ ed, 1992) $180 \mathrm{ff}$.

237 See, eg, Doreen McBarnet and Patrick Schmidt, 'Corporate Accountability through Creative Enforcement: Human Rights, the Alien Tort Claims Act and the Limits of Legal Impunity’ in Doreen McBarnet, Aurora Voiculescu and Tom Campbell (eds), The New Corporate Accountability: Corporate Social Responsibility and the Law (Cambridge University Press, 2007) 148 on tax and creative compliance.

238 John Braithwaite, Restorative Justice \& Responsive Regulation (Oxford University Press, 2002) 33.

239 See, eg, Joanna Gray and Jenny Hamilton, Implementing Financial Regulation: Theory and Practice (John Wiley \& Sons, 2006) 89-91.

240 Fisse and Braithwaite, above n 149, 469.

241 See Rogers, Kingsford Smith and Chellew, above n 21. 
procedures and personnel to enforce obligations imposed by statute and government regulation. The value of this is to bring peer assessments and expectations to bear on allegations of unsatisfactory conduct or misconduct.

In the wake of the GFC and of the LIBOR scandal, banking and finance entities have paid record fines to government regulators. Regardless, there has been much criticism of the absence of high-profile civil penalty or criminal prosecutions of those in authority in the lead up to the GFC, ${ }^{242}$ though this has changed somewhat with the LIBOR scandal. ${ }^{243}$ Along with the reforms we outlined in Part II, there have been calls for greater individual responsibility in banking, both civil and criminal. There is a firming view held by legislators, ${ }^{244}$ regulators, ${ }^{245}$ and judges ${ }^{246}$ that it is only by obtaining individual sanctions that conduct in banking and financial entities will improve. Fisse and Braithwaite captured this view 20 years ago when they wrote '[t]he impact of enforcement can easily stop with a corporate pay-out ... because that it is the cheapest and most self-protective course' ${ }^{247}$

There are changes in enforcement policy designed to target enforcement against individuals, in particular criminal prosecution. Under these policies, regulators will only enter settlements with a contravening entity if it hands over evidence of participation and potential culpability of executives, including for those who are senior and usually difficult to implicate. ${ }^{248}$ These enforcement changes address the difficulties even regulators with legislative power experience

242 In the US, see Raymond, above n 38. With regards to Australia, see, eg, Mark Weinberg, 'Some Recent Developments in Corporate Regulation - ASIC from a Judicial Perspective' (Paper presented at the Monash University Law School Commercial CPD Seminar, Melbourne, 16 October 2013) <http://www.austlii.edu.au/au/journals/VicJSchol/2013/9.pdf>; ASIC v Ingleby (2013) 39 VR 554, 561 (Weinberg JA); Elizabeth Macknay, 'Civil Penalty Settlement Agreements: A New Approach - ASIC $v$ Ingleby’ on Lexology (14 June 2013) <http://www.lexology.com/library/detail.aspx?g=9a016425-3fca42be-8722-947c3f0a9ad8>.

243 For example, the gaoling in the UK of banker Thomas Hayes for 14 years in August 2015 for the manipulation of the LIBOR rate whilst at UBS and Citigroup, even though he argued that his conduct was in line with his peers and was condoned by his superiors: see David Enrich, 'Former Trader Tom Hayes Sentenced to 14 Years for Libor Rigging’, The Wall Street Journal (online), 3 August 2015 $<$ http://www.wsj.com/articles/tom-hayes-convicted-of-libor-rigging-1438610483>.

244 In 2013, the UK Parliament enacted a new requirement (yet to become operational) to make senior managers of financial institutions responsible for breaches by those they supervise authorised to carry on financial services activity, where the senior manager did not take reasonable steps to stop the breach: Financial Services and Markets Act 2000 (UK) ss 66A(5)-(6), as amended by Financial Services (Banking Reform) Act 2013 (UK). See also Andrew Haynes, 'Banking Reform Struggles On’ (2015) 36 Statute Law Review 123.

245 In September 2015, the US Department of Justice issued the Yates Memo, under which the Department has stated it intends to step up its action against individuals involved in corporate contraventions: Memorandum from Sally Yates, Deputy Attorney General, US Department of Justice to Assistant Attorney General et al, 9 September $2015<$ https://www.justice.gov/dag/file/769036/download> ('Yates Memo').

246 In US Department of Treasury v Thomas Haider (Minn District Ct, Civ No 15-1518 (DSD/HB), 8 January 2016), the court upheld a claim for personal liability against a compliance officer, who failed to implement an effective anti-money laundering system and file suspicious transaction reports.

247 Fisse and Braithwaite, above n 149, 469. See also Herzberg and Anderson, 'Stepping Stones - From Corporate Fault to Directors’ Personal Civil Liability’ (2012) 40 Federal Law Review 181 for an account of the obligations of Australian corporate officers as opposed to those of the entity.

248 These are the types of enforcement policies instigated by the Yates Memo, above n 244 . 
in enforcement against individuals. Given, as we have argued, the significant obstacles to associational regulation in banking, at least for the foreseeable future, it seems one of the limits of professionalism in banking is, and should be, in enforcement co-regulation.

\section{Professionalism, Standardisation and Online Distribution}

Throughout this article we have argued for a normative dimension to banking as part of any professionalisation. That call for normative content through professionalising is to address the radical vulnerability of banking clients. ${ }^{249}$ So our final conclusion about how banking might look in the future responds to a paradox between the almost 'utility-like' necessity for the sale and distribution of financial products and services to the general public and the quest for professionalism. How can the scale of digital distribution of financial products or credit be extended while working to develop and institutionalise professionalism? Our arguments in this article advocating for professional structure and practices would be for nothing if, through digitisation, banking made an irreversible departure from the conditions conducive to professionalising. The vulnerability of retail banking customers is especially real, but through online offerings their contact with banks is increasingly standardised, online and one of information provision, sales and distribution. These observations are also increasingly true of the provision of financial advice and stockbroking. Personal financial advisers, stockbrokers, investment managers, and trustees are islands of fiduciary obligation in a sea of standardisation and commodified distribution to customers. The closer these move to online distribution, the greater the danger that they become remote from the interpersonal relationship at the heart of professional logic. ${ }^{250}$

Given the desire for financial inclusiveness and the educative role that good advice can play, it is important that the digitisation of banking and finance considers not only access, convenience and cost, but also how to preserve appropriate advisory and professional elements. We think the response to this modern paradox of professionalism lies in 'designing in' professional values and practices to products, services, and online distribution. Many research and program trials are needed to understand what professional online design in banking might be, all of which must be left for another time. As the articles in this thematic Issue have argued, professionalism is adaptable and the professions can change, have changed, and are changing. If, in the online mode, the central principles remain responsive to the 'radical vulnerability' of the client through the duties to the public interest and client priority supported by professional association allegiance, there are reasons for optimism about the future of

249 Above n 190.

250 Dimity Kingsford Smith and Kirsty Williamson, 'How Do Online Investors Seek Information and What Does This Mean for Regulation?’ [2004] 2 Journal of Information Law and Technology, 12; Simone Degeling and Jessica Hudson 'Can Robo-Advisors be Fiduciaries?' (Paper presented at CLMR Practitioners’ Forum, Sydney, 10 March 2017) (copy kept on file with author). 
professionalism in banking and in other occupations which aspire to be professions. 